\title{
TÜRK SİLÂHLI KUVVETLERİ VE MİLLî SAVUNMA HIZMETI
}

\author{
Dr. Halit YILMAZ*
}

\section{GİRISŞ}

Devletten beklenen asgarî hizmetlerden birisi güvenliğin sağlanmasıdır. Güvenliğin iç güvenlik ve dış güvenlik şeklinde iki temel boyutu vardır. İç güvenlik polis teşkilâtıyla yürütülen kolluk hizmetine, dış güvenlik ise ordu teşkilâtıyla yürütülen millî savunma hizmetine vücut verir.

Demokratik bir sistemde gerek iç güvenlik gerekse millî savunma hizmetinin teşkilâtlarıyla birlikte açık bir şekilde tanımlanması ve bunların siyasal sorumluluğu taşıyan sivil otoriteye bağlanmış, ona tâbi kılınmış olması gereği tartışılmayacak konulardır. Diğer bir deyişle, bir ülkedeki kamu gücünü kullanan silâhlı teşkilâtların siyasal mercilerden bağımsız ya da özerk bir iradeye sahip olmaları düşünülemez.

Biz bu çalışmada Türk Silâhlı Kuvvetlerini hem teşkilât hem de millî savunma hizmeti açısından ele aldık. Buradaki temel amacımız Türk Silâhlı Kuvvetlerini teşkilât ve işleviyle hukuksal olarak incelemek ve ortaya koymaktır. $\mathrm{Bu}$ yapılırken pozitif hukukun demokratik ilkeler ya da beklentilere ne ölçüde cevap verdiğini de tartışma firsatı bulduk. Ele aldığımız bu konu demokratikleşme serüvenimizin yeni bir aşaması olarak kabul edilebilecek olan Avrupa Birliğine uyum sürecinde daha şimdiden tartışılmaya başlanmıştır. $\mathrm{Bu}$ tartışmanın gelecek dönemlerde de hararetleneceği öngörülebilir.

Konu ya da sorun Türk Silâhlı Kuvvetleri olduğunda tartışmaların siyasal boyutunun, hukuksal boyutundan çok daha önemli ya da belirleyici olduğu bir gerçektir. Bununla birlikte, bu durum hukuksal bir incelemenin önemsiz ya da yararsız olduğunu göstermez. Özellikle konumuz açısından hukuksal inceleme siyasal gerçekliği yansıtma gücünü hâlâ sürdürmektedir.

Akdeniz Üniversitesi Hukuk Fakültesi İdare Hukuku Anabilim Dalı Araştırma Görevlisi 


\section{MILLÎ SAVUNMA HİZMETINIIN ÖRGÜTLENIŞİ}

\section{A) BAŞKOMUTANLIK ve GENELKURMAY BAŞKANLIĞI}

\section{Yerinin Tarihsel Gelişimi \\ 1. Genelkurmay Başkanının Türkiye İdare Düzeni İçindeki}

Genelkurmay Başkanının konumu Türkiye'de 1924'ten beri tartışılan önemli konulardan biri olmuştur ${ }^{1}$. Türk Silâhlı Kuvvetlerinin (TSK) Türkiye tarihi ve siyasal yapısı içindeki yeri düşünüldügünde söz konusu tartışma büyük bir önem taşımaktadır.

Kurtuluş savaşı yıllarında Genelkurmay Başkanlığı, hükûmet içinde Erkân-1 Harbiye-i Umumiye Vekâleti adında ayrı bir bakanlıktı. Erkân-1 Harbiye-i Umumiye Vekâleti yanında Müdafa-i Milliye Vekâleti diğer bir deyişle Millî Savunma Bakanlığ 1 da mevcuttu. Her ikisi de ayrı ayrı bakanlık konumunda olduğu için bunlar arasında herhangi bir hiyerarşi mevcut değildi. 03.03.1924 tarihinde çıkarılan 429 sayılı Kanun ile Erkân-1 Harbiyei Umumiye Vekâleti kaldırılmış ve görevinde bağımsız Genelkurmay Başkanlığı kurulmuştu. 429 sayılı Kanun'a göre Genelkurmay Başkanı, Başbakanın inhası ve Cumhurbaşkanının onayı ile atanmakta ve Cumhurbaşkanına "niyabeten" (vekâleten) orduya emir ve komuta etmekteydi. Bu Kanun'dan Genelkurmay Başkanlığının, Millî Savunma Bakanlığının dışında ve ondan bağımsız olduğu anlaşılmaktaysa da nereye bağlı olduğu belli değildi ${ }^{2}$.

20.04.1924 tarih ve 491 sayılı Teşkilât-1 Esasiye Kanunu (1924 Anayasas1) silâhlı kuvvetlerin statüsünde bir değişiklik getirmemiştir. Teşkilât-1 Esasiye Kanunu'nun 40. maddesine göre, silâhlı kuvvetlerin komutası barışta Genelkurmay Başkanlığına ait olup, savaş zamanında bu görev Bakanlar Kurulunun teklifi üzerine Cumhurbaşkanı tarafından atanacak kişi tarafından yerine getirilecekti. Aynı maddede ayrıca, Başkomutanlığın Türkiye Büyük Millet Meclisinin (TBMM) manevi kişiliğine ait olduğu ve Cumhurbaşkanınca temsil olunacağ düzenlenmişti. Bu hüküm 1961 ve 1982 Anayasalarında da yer almıştır³.

05.06.1944 tarih ve 4580 sayılı Genelkurmay Başkanlığının Vazife ve Salahiyetleri Hakkında Kanun'un 1. maddesinin 2. fikrasıla, "Hazarda Genelkurmay Başkanlığı Başvekile bağgl ve emir komutadan ve genelkurmay işlerinden ona karşı mesuldür." düzenlemesi getirildi. Böylece 1944-1949 yılları arasında Genelkurmay Başkanlığı Başbakanlığa bağlı kaldı. 30.05.1949 tarihli ve 5398 sayılı Millî Savunma Bakanlığının Kuruluş ve

Bkz. Özdemir, H.: Rejim ve Asker, İstanbul 1989, s. 57-86.

Kıratlı, M.: Koruyucu İdarî Hizmetler, Ankara 1973, s. 103; Erdoğan, M.: Anayasa ve Özgürlük, Ankara 2002, s. 242; Özdemir (1989), s. 57.

3 Erdoğan (2002), s. 242-243; Özdemir (1989), s. 61-62. 
Görevleri Hakkında Kanun ile Genelkurmay Başkanlığı, Millî Savunma Bakanlığına bağlandı ve onun bir dairesi haline getirildi ${ }^{4}$.

1960 öncesi TSK'nın partizanca tutumlara ve sindirme girişimlerine alet edilmek istenmesi, 27 Mayıs darbesinden sonraki Anayasa hazırlama sürecinde tepkisini bulmuş, TSK'ya özel, hatta "özerk" bir yer verme eğilimi yaratmış ve bu bakımdan askerî çevrelerden gelen istekler aşırı boyutlara varmıştı ${ }^{5}$. Örneğin, Genelkurmay Başkanlığının doğrudan Cumhurbaşkanına bağlanması suretiyle, siyasal sorumluluk mekanizmasının dışına çıkarılmasına yönelik çözümler bile tartışılmıştı ${ }^{6}$.

1961 Anayasas1, 30.05.1949 tarih ve 5398 sayılı Kanun ile gelinen noktanın bir adım gerisine giderek Genelkurmay Başkanlığı için idare düzeni içinde yeni bir konum yaratmıştı. 1961 Anayasası'nın 110. maddesi, savaş ve barış ayrımı yapmadan TSK'nın komutanlığını Genelkurmay Başkanına vermiş ve Genelkurmay Başkanının Başbakana karşı sorumlu olduğunu ve Bakanlar Kurulunun teklifi üzerine Cumhurbaşkanınca atanacağını öngörmüştü. Böylece, Genelkurmay Başkanının devlet içindeki konumu, günümüze kadar yansiyan bu düzenlemeyle belirlenmiştir.

1961 Anayasası ile getirilen yeni statü Anayasa Mahkemesinin verdiği kararlarla pekişmiştir. Anayasa Mahkemesi 5398 sayılı Kanun'un Genelkurmay Başkanlığını Millî Savunma Bakanlığına bağlayan 1 . maddesini Anayasa'ya aykırı bularak 1966 yılında iptal etmiştir. Aynı kararda, Millî Savunma Bakanlığının bazı işlerini Genelkurmay Başkanlığı aracılığıyla yapacağını öngören 2. madde ve Genelkurmay Başkanının Millî Savunma Bakanlığının teklifi üzerine Bakanlar Kurulunca atanmasını öngören 3. madde Anayasa'ya aykırı bulunarak iptal edilmişti. Anayasa Mahkemesinin gerekçesi şöyleydi: "...Anayasa, Genelkurmay Başkanını savaşta ve barışta Silâhlı Kuvvetlerin komutanı olarak göstermiş, böylece Türk Ordusunun hazırlanması ve yönetilmesi görevini, Genelkurmay Başkanına vermiş, buna karşıllı da onu, Başbakana karşı sorumlu tutmuştur. Anayasa'nın bu kuralına göre, Genelkurmay Başkanının, kaynă̆ını Anayasa'dan alan görevlerini, bir bakan adına ve Bakanlığın bir idaresi olarak değil, kendi adına ve Başbakana karşı sorumlu olarak yürütmesi gerekmektedir. 110. maddenin son fikrasına göre, bu görev ve yetkileri düzenleyecek olan yasanın söz konusu Anayasa kuralını göz önünde tutması gerekir. Esasen MSB ve Genelkurmay Başkanlı̆̆ arasında idarî bir bağlantı kurulması, Anayasa Koyucu tarafindan da kabul edilmemiştir. Buna göre, Genelkurmay Başkanlığının, MSB'na onun bir dairesi halinde

Kıratlı (1973), s. 103; Özdemir (1989), s. 70-86.

Soysal, M.: 100 Soruda Anayasanın Anlamı, 11. bası, İstanbul 1997, s. 234.

Onar, S. S.: İdare Hukukunun Umumi Esasları, C. II, İstanbul 1966, s. 766, d.n. 100; Soysal (1997), s. 234. 
bă̆lanması, Bakanlık bünyesi içinde (Genelkurmay Başkanlığı) ve (Müsteşarlık) adı ile iki daire kurulması ve bu Bakanlığın, Anayasa'ya aykırı olarak kendisine verilmiş bulunan bu görevlerini, Genelkurmay Başkanliğ ve Müsteşarlık aracıllğ bağdaşmamaktadır." "Dava konusu 3. madde de, Genelkurmay Başkanının atanma işlemi, Anayasa'nın 110. maddesiyle konulmuş bulunan ilkeden ayr bir biçimde düzenlenmiştir." "...dava konusu kurallar Anayasa'nın 110. maddesine aykurıdır." ".

Anayasa Mahkemesinin bu kararından sonra çıkarılan 31.07.1970 tarihli, 1324 sayılı Genelkurmay Başkanının Görev ve Yetkilerine Ait Kanun ve 31.07.1970 tarihli, 1325 sayılı Millî Savunma Bakanlığının Görev ve Teşkilâtı Hakkında Kanun ile bu iki idarî teşkilât birbirinden tamamen ayrılmış ve aralarındaki ilişki düzenlenmiştir.

Millî Savunma Bakanlığına ilişkin 1325 sayılı Kanun Anayasa Mahkemesinde iptal davasına konu olmuş ve Kanun'un 4. maddesi Kara, Hava ve Deniz Kuvveleri Komutanlıklarını, Millî Savunma Bakanlığının bazı görevlerini yerine getirmekle yükümlendirdiği için 1971 yılında kısmen iptal edilmiştir. Ayrıca, Millî Savunma Bakanlığı ve Genelkurmay Başkanlığının kuvvet komutanlıklarıyla yaptıkları önemli yazışmaları birbirlerine haber verme yükümlülüğünü düzenleyen aynı Kanun'un 6 . maddesi de "Millî Savunma Bakaninin gerektiğinde Kuvvet Komutanlıklarına doğrudan doğruya buyruk verebileceği ve birtakım hizmetleri bunlara gördürebileceği" gerekçesiyle iptal edilmiştir ${ }^{8}$.

Anayasa Mahkemesinin bu kararlarında, Genelkurmay Başkanlığını Millı̂ Savunma Bakanlığının bir dairesi olmasından rahatsızlık duyduğu ve silâhlı kuvvetleri siyasal iktidarın etkisinden korumak kaygısını taşıdığı ileri sürülmüştür?'.

\section{Genelkurmay Başkanlığının Başbakanlık ve Millı̂ Savunma} Bakanlığı Karşısındaki Konumu

İdarî teşkilâtın temel ilkeleri Anayasa'da yer alır. Anayasa İdareyi "Yürütme" bölümünün "İdare" alt başlı̆ğında düzenlemiştir. Bu sistematiğe göre, idare, yürütme içinde onun bir parçası olarak düşünülmekle beraber, yürütme organının salt siyasal nitelikli işlevinin dışında kalan işlevini yerine getirmesinin aracı olması nedeniyle ayrı bir başlık altında düzenlenmiştir ${ }^{10}$.

\footnotetext{
A.M., E. 1963/67, K. 1966/19, KT. 14.4.1966, A.M.K.D., S.4, s. 268-276.

A.M., E. 1970/52, K. 1971/46, K.T. 27.04.1971, A.M.K.D., S. 9, s. 492-503.

Erdoğan (2002), s. 244.

10 Günday, M.: İdare Hukuku, 8. baskı, Ankara 2003, s. 7-9; Gözler, K.: İdare Hukuku, C. I, Bursa 2003, s. 22-25.
} 
Anayasa'nın 123. maddesine bakıldığında, karşılaşılan ilk ilke "idarenin kuruluş ve görevleri ile bir bütün olması ve kanunla düzenlenmesi"dir. Yine aynı maddeye göre "idare merkezden yönetim ve yerinden yönetim esasları"na göre düzenlenir.

Merkezden yönetim esasına göre, merkez örgütü, merkezî ya da genel idare, Cumhurbaşkanı, Bakanlar Kurulu ve merkezdeki yardımcı kuruluşlardan oluşmaktadır. Ülke düzeyinde yürütülen idarî hizmetlerin tek bir merkezden yönetilmesi esasına dayanan merkezden yönetim uygulamasında, her bir idarî hizmet ve bu hizmetleri yürüten idarî birimler bakanlıklara bağlanmışlardır. Bakanlar bu idarî hizmetlerin en yüksek amiri konumundadır. Yürütmenin parlamentoya karşı olan siyasal sorumluluğu düşünüldüğünde, kural olarak herhangi bir bakanlığa bağlı olmayan idarî merci ve hizmet düşünülemez.

Yerinden yönetim uygulaması da "yer yönünden" ve "hizmet yönünden" yerinden yönetim birimlerini doğurmuştur. Yer yönünden yerinden yönetim birimleri İl Özel İdaresi, Belediye ve Köy olarak adlandırılan "yerel yönetim" organlarıdır. Bunlar Anayasa'nın 127. maddesine göre, belli bir bölgede yaşayan insanların ortak ihtiyaçlarını karşılamak için devlet tüzel kişiliğinin yanında ayrıca oluşturulan tüzel kişiliklerdir. Hizmet yerinden yönetim kuruluşları ise, özellik arz eden belli hizmetlerin tüzel kişilik olarak örgütlenmeleriyle ortaya çıkmışlardır. Anayasa idarenin bütünlüğü ilkesini getirmiş olduğu için devlet tüzel kişiliğinden ayrı tüzel kişiliklerin varlığını devlet tüzel kişiliği ile ilişkilendirmek bir zarurettir. Bunun için yerinden yönetim kuruluşları üzerinde merkezî idareye "vesayet yetkisi" tanınmıştır"1 .

Genel bir çerçevesini çizdiğimiz idare teşkilâtının içerisinde TSK nerede durmaktadır? Bu sorunun cevabı için öncelikle Anayasa'nın 117. maddesine bakmak gerekir. 1982 Anayasası Genelkurmay Başkanının konumu ve TSK'nın komutanlığı bakımından 1961 Anayasası'ndan farklı bir düzenleme getirmemiştir. 1982 Anayasası'nın 117. maddesinin konuya ilişkin hükümleri şöyledir:

"Başkomutanlık, Türkiye Büyük Millet Meclisinin manevi varlı̆̆ından ayrlmaz ve Cumhurbaşkanı tarafindan temsil olunur."

"Millî güvenliğin săglanmasindan ve Silâhlı Kuvvetlerin yurt savunmasına hazırlanmasından, Türkiye Büyük Millet Meclisine karşı, Bakanlar Kurulu sorumludur."

11 Yıldırım, T.: Türkiye'nin İdarî Teşkilâtı, 2. baskı, İstanbul 1999, s. 31-74; Duran, L.: İdare Hukuku (Ders Notları), İstanbul 1981, s. 73-102; Günday (2003), s. 61-65, s. 7478. 
"Genelkurmay Başkanı; silâhlı kuvvetlerin komutanı olup, savaşta Başkomutanlık görevlerini Cumhurbaşkanlığı namına yerine getirir."

"Genelkurmay Başkanı, Bakanlar Kurulunun teklifi üzerine, Cumhurbaşkanınca atanır; görev ve yetkileri kanunla düzenlenir. Genelkurmay Başkanı, bu görev ve yetkilerinden dolayı Başbakana karşı sorumludur."

"Millî Savunma Bakanlığının, Genelkurmay Başkanlı̆̆ı ve Kuvvet Komutanlıkları ile görev ilişkileri ve yetki alanı kanunla düzenlenir."

Öncelikle TSK'nın idarî bir birim olduğundan ve idarî bir işlev gördügünden şüphe yoktur. Oysa Anayasa'da TSK'nın gerek işlevi ve gerekse organik konumunu düzenleyen 117. madde "İdare" alt başlı̆̆ altında değil, doğrudan "Yürütme" başlığg altında yer almıştır. Bunun sebebi, yine Anayasa'nın 117. maddesinde silâhlı kuvvetlerin yurt savunmasına hazırlanmasından Bakanlar Kurulunun sorumlu olmasıdır. $\mathrm{Bu}$ makul açıklamaya rağmen, TSK'ya ilişkin düzenlemelerin "İdare" alt başlı̆̆ altında yer almaması, Anayasa'nın TSK'ya klasik idarî yapılanma dışında özel bir önem verdiğinin ilk göstergesidir.

Anayasa silâhlı kuvvetlerin "komutanlığı" ve "başkomutanlı̆̆ı" şeklinde bir ayrım yapmıştır. Anayasa'nın 117. maddesinin 1. fikrasında Başkomutanlığın TBMM'nin manevi varlığından ayrılamayacağı ifade edilmiştir. Anayasa'nın 87. ve 92. maddelerinin savaş ilanına karar verme ve silâhlı kuvvetlerin kullanılmasına izin verme yetkisini TBMM'ne vermesi çerçevesinde Anayasa'nın 117. maddesinin 1. fikrası belli bir anlam kazanıyor. Bunun dışında Anayasa'nın 117. maddesinin 1. fikrasının hukuk uygulamas1 bakımından ciddî bir değerinin bulunduğu şüphelidir. TBMM'nin manevi varlığına bağlı bir statünün, ilke olarak pozitif bir görünümü yoktur. Nitekim aynı fikrada Başkomutanlığın Cumhurbaşkanı tarafindan temsil olunacağ 1 ifade edilerek Başkomutanlık statüsü somutlaştırılmıştır. Ancak, 117. maddenin 3. fikrasında savaş zamanlarında Başkomutanlık görevinin Cumhurbaşkanı adına Genelkurmay Başkanı tarafından yürütüleceği ifade edilmiştir.

Başkomutanlık statüsü, hiyerarşik olarak komutanlık statüsünün üstünde kabul edilmek gerekir. Anayasal düzenlemeye göre Başkomutanlığg Cumhurbaşkanı temsil ettiğine göre Cumhurbaşkanı Genelkurmay Başkanının amiri midir? Bunu böyle yorumlasak bile, Cumhurbaşkanının icraî yetkileri bulunmadığı için, Başkomutanlık statüsünün daha çok sembolik ya da geleneksel bir anlamı vardır. Bununla birlikte Anayasa'nın 92. maddesinin 2. fikrasındaki "Türkiye Büyük Millet Meclisi tatilde veya ara vermede iken ülkenin ani bir silâhlı saldırlya uğraması ve bu sebeple silâhlı kuvvet kullanılmasına derhal karar verilmesinin kaçınılmaz olması halinde Cumhurbaşkanı da, Türk Silâhlı Kuvvetlerinin kullanılmasına karar 
verebilir." hükmü akla gelebilir. Ancak bu hüküm de aktif bir başkomutanlık yetkisini değil istisnaî bir yetkiyi düzenlemektedir.

Başkomutanlık konusunun bu şekilde sembolik olarak düzenlenmesinin tarihsel sebepleri vardır. Nitekim Anayasa'nın 117. maddesinin gerekçesinde bu konu şu şekilde ifade edilmiştir: "Başkomutanlık; bir anane olarak Birinci Büyük Millet Meclisinden beri devam eden ve millî egemenliğin kayltsiz şartsız temsilcisi olan Türkiye Büyük Millet Meclisinin manevi varlı̆̆ından ayrlmayacağ l ve Devletin başı olan ve bu sıfatla Türkiye Cumhuriyetini ve Türk Milletinin birliğini temsil eden Cumhurbaşkanı tarafindan temsil olunacağına işaret edilmiştir." ${ }^{12}$

Anayasa'nın 117. maddesinde dikkati çeken daha önemli bir başka konu Genelkurmay Başkanının Başbakana karşı sorumlu olmasıdır. Silâhlı kuvvetlerin yurt savunmasina hazırlanmasından Bakanlar Kurulu sorumlu tutulmuşken, TSK'nın hiyerarşik olarak en üstteki amiri Genelkurmay Başkanı Başbakana karşı sorumlu tutulmuștur. TSK'nın, millî savunma hizmetinin yürütülmesinin siyasî sorumluluğunu taşıyan hükûmetten bağımsız olması söz konusu olamaz. Bu nedenle, Genelkurmay Başkanı her ne kadar Bakanlıklara karşı bağımsız olarak örgütlenmişse de Anayasa'nın 117. maddesiyle Başbakana karşı sorumlu tutulmuştur ${ }^{13}$. Ancak aşağıda da inceleneceği gibi, TSK Başbakanlık bağlı kuruluşu değildir ve bu sorumluluğun nasıl bir hukuksal ilişki olduğu tartışmalıdır.

TSK'nın idarî teşkilât içindeki yerini belirlemek için Genelkurmay Başkanının Başbakana karşı sorumlu olmasının ne anlama geldiğini sorgulamak gerekir.

Türkiye'de bazı hizmet birimleri, tıpkı bir hizmet bakanlığıymış gibi, Başbakana bağlanmıştır. Ancak, uygulamada Başbakan kendisine bağlanan idarî birimlerle doğrudan ilgilenmemektedir. Bu birimlerle devlet bakanları ilgilenmektedir. Başbakana karşı sorumlu kılınan Genelkurmay Başkanlığg ile herhangi bir devlet bakanı ilgilenmemektedir ${ }^{14}$ ya da bu tür bir yöntem şimdiye kadar denenmemiştir. Bu durum sadece uygulamada gözlenen bir durum olmak itibariyle bizim için çok bir şey ifade etmemektedir.

Normatif açıdan bakıldığında, öncelikle belirtmek gerekir ki, Anayasa koyucu Genelkurmay Başkanlığının "Başbakanlığa bağlı" olduğunu ifade etmekten kaçınmıştır. Sorumluluk ilişkisiyle birlikte bu tür bir düzenleme getirilmiş olsaydı, Başbakan ve Genelkurmay Başkan arasındaki ilişkinin hukuksal niteliğini belirlemek adına ilk önemli veriyi elde etmiş olurduk. Bu

12 Akad, M./Dinçkol, A.: 1982 Anayasası, Madde Gerekçeleri ve Maddelerle İlgili Anayasa Mahkemesi Kararları, İstanbul 1998, s. 449-450.

13 Erdoğan (2002), s. 248.

14 Gözübüyük, Ş./Akıllığlu, T.: Yönetim Hukuku, Ankara 1992, s. 69. 
arada hemen belirtmek gerekir ki, Başbakan ve Genelkurmay Başkanı arasındaki ilişkinin içeriği yasal düzenlemelerde de somutlaştırılmış değildir. Hiyerarşik yetkilerin yasal düzenleme gerektirmediği iddia edilebilir. Ancak, belirli ya da kendine özgü idarî hizmet gören bir teşkilât ile merkezî idare arasında hiyerarşik ilişkinin kurulabilmesi için söz konusu teşkilâtın merkezî yönetime bağlı ve ona karşı sorumlu olduğunun yasayla belirlenmesi kanaatimce asgari şarttır. Ancak bu düzenleme yapıldıktan sonra hiyerarşi ilişkisinin içerdiği yetkilerin yasayla ayrıca belirlenmesi gerekmez.

ERDOĞAN, Anayasa'nın 117. maddesindeki düzenlemeye göre, Başbakanın Genelkurmay Başkanının hiyerarşik üstü olduğunu söylemenin zor olduğunu, Başbakanın Genelkurmay Başkanına vereceği talimatların askerî teknik konulara ilişkin olmaktan çok, millî güvenlik ve savunma politikalarına uygun olarak yön gösterici, çerçeve nitelikte talimatlar olduğunu ifade etmektedir. Buna göre, Genelkurmay Başkanı görev ve yetkilerinden dolayı Başbakana karşı sorumlu olmakla birlikte, yetkilerini onun onayı ile veya vesayeti altında kullanması gerekmez. Başka bir deyişle, silâhlı kuvvetlerin komutanı kendi görev alanında herhangi bir makamın onayına gerek kalmadan işlem yapabilme yetkisine sahiptir. Esasen, sorumluluğun bir anlamının olabilmesi için, bir makamın kendi görevini başka makam ve organlardan esas itibariyle bağımsız olarak yapıyor olması gerekir. Genelkurmay Başkanı ve Başbakan arasındaki ilişkide söz konusu olan sorumluluk ilişkisinin anayasa hukukundakine yakın bir anlamı olduğu savunulmaktadır. Anayasa hukuku bakımından sorumluluk, bir kişi ya da makamın görevine, kendisine karş1 sorumlu bulunduğu makam tarafindan son verilebilmesi anlamına gelir. Bu bağlamda Genelkurmay Başkanının sorumluğu, hükûmetin gerektiğinde onun görevine son verebilmesi anlamına gelmektedir. Hükûmet bakımından bu bir siyaset sorunudur. Başbakan Genelkurmay Başkanına, hükûmetin millî güvenlik ve millî savunma politikası doğrultusunda, teknik ayrıntıyla ilgili olmayan genel, yön gösterici direktifler verebilir. Bu konudaki performans1 yetersiz bulunan Genelkurmay Başkanının görevden alınması için Başbakan, Bakanlar Kurulunu harekete geçirebilir ${ }^{15}$.

$\mathrm{Bu}$ yoruma mevcut düzenlemeler açısından genel olarak biz de katıliyoruz. Ancak, bu yoruma küçük bir katk1 yapmak yerinde olabilir. Çünkü, "sorumluluk" kavramının anayasa hukukundakinden farklı olarak idare hukukundaki anlamı iki idarî merci arasındaki ilişkiyi hiyerarşi ilişkisine indirgemek yönünden daha dar olabilir. $\mathrm{Bu}$ durum özellikle merkezî yönetim ve tüzel kişiliğe sahip olmayan idarî merciler arasındaki ilişkileri açıklamak bakımından böyledir. O halde, Anayasa'nın 117. maddesinin 4. fıkrasındaki "Genelkurmay Başkanı Başbakana karşı

$15 \quad$ Erdoğan (2002), s. 137. 
sorumludur" hükmünü "sorumluluk" kavramının belli bir özerkliği beraberinde getirdiği yolundaki yorumla birlikte okumak her zaman doğru olmayabilir. Örneğin, Başbakanlık bağlı kuruluşu olan Devlet Meteoroloji İşleri Başkanlığının kuruluş kanunu olan 08.01.1986 tarihli ve 3254 sayılı Devlet Meteoroloji İşleri Genel Müdürlüğü Teşkilât ve Görevleri Hakkında Kanun'un 5. maddesi Genel Müdürün Başbakana karşı sorumlu olduğunu düzenlemiştir. Yine 26.09.1984 tarih ve 3045 sayılı Tapu ve Kadastro Genel Müdürlüğü Kuruluşu ve Görevleri Hakkında Kanun Hükmünde Kararnamenin Değiştirilerek Kabulü Hakkında Kanun'un 5. maddesine göre Genel Müdür Başbakana karşı sorumludur ${ }^{16}$. Gerek Devlet Meteoroloji İşleri Genel Müdürlüğü gerekse Tapu ve Kadastro Genel Müdürlüğü tüzel kişiliği olmayan idarelerdir. İdare hukuku anlamında Başbakanın ve Başbakanlık Müsteşarının bu kuruluşların genel müdürlerinin hiyerarşik amiri olduğunu söyleriz. Bununla birlikte, söz konusu kanunlarda Devlet Meteoroloji İşleri Genel Müdürlüğü ile Tapu ve Kadastro Genel Müdürlüğünün Başbakanlık bağlı kuruluşu olarak nitelendirildiğini de gözden rak tutmamak gerekir ${ }^{17}$. Bağlı kuruluş nitelendirmesi olmadan Başbakanın söz konusu kuruluşların genel müdürlerinin hiyerarşik amiri olduğunu rahatlıkla ifade etmek mümkün olmayabilirdi. Nitekim 10.10.1984 tarihli ve 3054 say1l Başbakanlık Teşkilâtı Hakkında Kanun Hükmünde Kararnamenin Değiştirilerek Onaylanması Hakkında Kanun'un 3. maddesinin 1. fikrası "Başbakanlık Teşkilâtı; merkez teşkilâtı ile bağlı ve ilgili kuruluşlardan meydana gelir." hükmünün ardından, 4. maddesinin 1. fikrasında "Başbakan... Başbakanlı Teşkilâtının en üst amiridir." hükmünü getirmiştir ${ }^{18}$. Dolayısıyla bir idarî birimin, bağlı ya da ilgili kuruluş olarak nitelendirilmesi bağlı ya da ilgili olduğu bakanlık ya da Başbakanlık

27.11.2002 tarihli ve 24949 sayll Resmi Gazete'de yayımlanan, 26.11.2002 tarihli 2002/792 sayılı Bakanlar Kurulu Kararnamesi ile Devlet Meteoroloji İşleri Genel Müdürlüğü Çevre Bakanlığına, Tapu ve Kadastro Genel Müdürlüğü de Bayındırlık ve İskân Bakanlığına bağlanmıştır.

$17 \quad$ 14.02.1985 tarih ve 3152 sayılı İçişleri Bakanlığı Görev ve Teşkilâtı Hakkında Kanun'un 29. maddesi Jandarma Genel Komutanlığının İçişleri Bakanlığının “bağlı kuruluș”u olduğunu ifade etmiştir. 10.3.1983 tarihli ve 2803 sayıl Jandarma Teşkilât, Görev ve Yetkileri Kanunu'nun 4. maddesi de Jandarma Genel Komutanının İçişleri Bakanına karșı "sorumlu" olduğunu belirtmiştir. 01.11.1983 tarih ve 2937 sayılı Devlet İstihbarat Hizmetleri Ve Millî İstihbarat Teşkilâtı Kanunu'nun 3/1. maddesine göre, "Başbakana bağlı Millî İstihbarat Teşkilâtı Müsteşarlığı kurulmuştur." Aynı Kanun'un 7. maddesine göre ise, "MíT Müsteşarı... görevlerin yerine getirilmesinden Başbakana karşı sorumlu olup, Başbakanın dışında herhangi bir kişi veya makama karşı sorumlu tutulamaz." Örnekleri çoğaltmak mümkündür.

183056 sayılı Başbakanlık Teşkilâtı Hakkında Kanun Hükmünde Kararnamenin Değiştirilerek Onaylanması Hakkında Kanun'un 4. maddesinin 1. fikrası "Başbakan... Başbakanlık Teşkilâtının en üst amiridir." düzenlemesini getirse de Başbakanın tüzel kişiliği bulunan Başbakanlık bağlı ya da ilgili kuruluşlarının hiyerarşik olarak en üst amiri olduğunu düşünmek mümkün değildir. Kanun'un burada tüzel kişiliği bulunan kuruluşlarla tüzel kişiliği bulunmayan kuruluşlar arasında bir ayrım yapması yerinde olurdu. 
arasındaki ilişkileri belirleyebilmemiz açısından önem taşı1 ${ }^{19}$. Bu bağlamda, Genelkurmay Başkanlığı açıkça Başbakanlığa bağlanmadığı veya onunla ilişkilendirilmediği için bu ikisi arasındaki ilişkinin hukuksal niteliğinin netlik taşımadığını ifade edebiliriz.

Bazı yazarlar Genelkurmay Başkanlığını, Başbakanlığa bağlı ya da Başbakanlığın ilgili kuruluşları arasında saymaktadır ${ }^{20}$. Gerçekten, Genelkurmay Başkanının Başbakana karşı sorumlu olduğunun belirtilmesi, Genelkurmay Başkanlığını ve dolayısıyla TSK'yı Başbakanlığın bağlı kuruluşu olarak düşünmemize yol açabilir. Ancak, millî savunma hizmeti bakımından Başbakanlık, Millî Savunma Bakanlı̆̆ı ve Genelkurmay Başkanlığı arasındaki ilişkiler düşünüldüğünde Genelkurmay Başkanlığının Başbakanlığın bağlı kuruluşu olduğunu söylemek zordur. Öncelikle, yasal düzenlemelerde Genelkurmay Başkanlığının Başbakanlığın bağlı kuruluşu olduğuna yönelik açık bir hüküm yoktur. Bu tür bir düzenleme olmadan bağlı ya da ilgili kuruluş nitelendirmesi yapmak mümkün değildir. İkinci olarak, eğer Genelkurmay Başkanlığı Başbakanlığın bağlı kuruluşudur dersek, millî savunma hizmetinden doğan davalarda husumetin Başbakanlığa yöneltilmesi gerekirdi. Çünkü, Genelkurmay Başkanlığının tüzel kişiliği yoktur. Oysa millî savunma hizmetinden doğan davalar, 1325 sayılı Millî Savunma Bakanlığı Görev ve Teşkilâtı Hakkında Kanun'un 2/a maddesine göre Millî Savunma Bakanlığına yöneltilmektedir. Ayrıca, aynı Kanun'un 2/b maddesine göre, TSK'nın, savunma sanayii ihtiyaçlarının bir kısmı hariç $^{21}$, bütün ihtiyaçları doğrudan Millî Savunma Bakanlığı eliyle ve bütçesiyle karşılanmaktadır. $\mathrm{Bu}$ düzenlemeler açısından bakıldığında, Genelkurmay Başkanlığının Başbakanlığın bağlı kuruluşu olduğunu söylemek mümkün değildir.

9 Konunun önemini vurgulamak için, Anayasa Mahkemesinin bir kararına değinmek gerekir. 03.01.2002 tarih ve 4733 sayıl1 "Tütün, Tütün Mamulleri, Tuz ve Alkol İșletmeleri Genel Müdürlüğünün Yeniden Yapılandırılması ile Tütün ve Tütün Mamullerinin Üretimine, İç ve Dış Alım ve Satımına, 4046 Sayılı Kanun'da ve 233 Sayılı Kanun Hükmünde Kararnamede Değişiklik Yapılmasına Dair Kanun”un 2. maddesinin 1. fikrasında “...Kurum, Başbakanın görevlendireceği bir Devlet Bakanı ile ilişkilendirilir." hükmü yer almıştır. Anayasa Mahkemesi sadece Kanun'un 2. maddesindeki "bakanlıkla ilişkilendirilir" hükmünü, ilişkilendirilen Bakanlığın yetkilerinin somut olarak belirlenip belirlenmediğini test etmeden, idarenin bütünlüğü ilkesinin sağlanması açısından yeterli bulmuştur. A.M., E. 2002/32, K. 2003/100, K.T. 11.08.2004, R.G. 11.08.2004, S. 25550.

20 Serim, B.: Anayasa ve Anayasa Mahkemesi Kararları Işı̆̆ında Özelleştirme, Ankara 1996, s. 79; Demirkol, S./Bereket, Z.: İdarî Yargıda Dava Açma ve Davaların Takip Usulü, Ankara 1998, s. 70.

213238 sayılı Savunma Sanayii Müsteşarlığının Kuruluşu Hakkındaki Kanun’un kapsamına giren silâh ve gereçlerin tedariki savunma sanayii kuruluşları tarafından gerçekleştirilmektedir. 
Sonuç olarak, Genelkurmay Başkanlığının Başbakanlığa bağlı olduğunun ya da Genelkurmay Başkanının işlemlerinin Başbakan tarafindan onaylanacağının kanunla düzenlenmesinin, diğer bir deyişle Başbakan ve Genelkurmay Başkanı arasında klasik hiyerarşi ilişkisi kurulmasının Anayasa'ya aykırı olmayacağını belirtmek gerekir. Diğer bir deyişle Anayasa'daki düzenlemenin Başbakan ve Genelkurmay Başkanı arasında hiyerarşi ilişkisi kurulmasına engel teşkil ettiğini söylemek mümkün değildir.

Özetle, Genelkurmay Başkanlığının Başbakanlığın bağlı kuruluşu olduğu düzenlenmediği sürece Anayasa'nın 117. maddesinin 4. fikrasındaki "Genelkurmay Başkanı Başbakana karşı sorumludur" hükmünü Başbakan Genelkurmay Başkanı üzerinde klasik hiyerarşik yetkilere sahiptir ya da Başbakan Genelkurmay Başkanının hiyerarşik amiridir şeklinde yorumlamamız mümkün değildir. Diğer bir deyişle, Genelkurmay Başkanının Başbakana karşı sorumlu olması idarî anlamda Başbakana bağlı olduğu anlamına gelmez ${ }^{22}$. Açı yasal belirlemeler olmadığ 1 için Başbakanlık ve Genelkurmay Başkanlığı arasında, tabir yerinde ise, belli bir "mesafe" bulunduğu bu mesafenin Genelkurmay Başkanlığına belli bir özerklik bahşettiği gerçektir. Bu tür bir ilişki biçiminin örneğin İçişleri Bakanlığ 1 ile Emniyet Genel Müdürlüğü arasında olamayacağını kabul ediyorsak, Başbakanlık ve Genelkurmay Başkanlığı arasında da olamayacağını kabul etmeliyiz. Emniyet Genel Müdürlüğünün hizmet alanının iç güvenlik ve kamu düzeni olması, TSK'nın hizmet alanının dış güvenlik ve millî savunma olması kıyas olanağını ortadan kaldırmaz. Her iki idarenin de "silâhlı güç" olması yerindelik açısından tam bir kıyas olanağı sunmaktadır.

TSK'nın Türkiye idare düzeni içindeki yeri incelenirken Millî Savunma Bakanlığını ve bu Bakanlığın TSK ile ilişkisini ele almak gerekiyor. Gerçekten Genelkurmay Başkanlığ1 ve Millî Savunma Bakanlığ1 arasındaki ilişkileri ortaya koymadan TSK'nın idare düzeni içindeki konumunu net bir şekilde ortaya koymak mümkün değildir. Anayasa'nın 117. maddesinde TSK herhangi bir bakanlıkla ilişkilendirilmemiştir. TSK'nın Millî Savunma Bakanlığına bağlı olması benimsenebilecek en olağan düzenleme olurdu. Ancak, gerek Anayasa'daki düzenleme gerekse kanunlardaki düzenlemeler, Millî Savunma Bakanlığını, Genelkurmay

22 Akgüner, T.: 1961 Anayasasına Göre Millî Güvenlik Kavramı ve Millî Güvenlik Kurulu, İstanbul 1983, s. 135; Aynı yönde bkz. Erdoğan (2002), s. 251. AKGÜNER Genelkurmay Başkanının Başbakana karşı sorumlu olmasının idarî anlamda Başbakana bağlı olduğu anlamına gelmeyeceğini kabul etmekle birlikte, Bakanlar Kurulunun saptadığı millî güvenlik ve savunma politikalarının uygulanması konusunda Başbakanın Genelkurmay Başkanına "emir ve direktifler verebileceği" ve bunun da hiyerarşik yetkiler kapsamına gireceğini kabul etmektedir. Akgüner (1983), s. 134. 
Başkanlığı ve Kuvvet Komutanlıkları karşısında olağan bakanlık görev ve yetkilerinden yoksun hale getirmiştir ${ }^{23}$. Bu değerlendirme elbette ki olmas1 gereken bakımından yapılmıştır.

Her şeyden önce Anayasa'nın 117. maddesinin, “Millî Savunma Bakanlığının, Genelkurmay Başkanlı̆̆ ve Kuvvet Komutanlıklarl ile görev ilişkileri ve yetki alanı kanunla düzenlenir." şeklindeki son fikrasına dikkat çekmek gerekir. $\mathrm{Bu}$ maddede ifade sıkıntısı olduğunu belirtelim. Düzenlemedeki "yetki alanı" ifadesi bizatihi ve kendi halinde Millî Savunma Bakanlığına mı eklemlenmektedir yoksa Millî Savunma Bakanlığı, Genelkurmay Başkanlığı ve Kuvvet Komutanlıkları arasındaki ilişkilere mi eklemlenmektedir? Diğer bir deyişle düzenlemeyi "Millî Savunma Bakanlığının... yetki alanı kanunla belirlenir." şeklinde mi okumalıyız, yoksa "Millî Savunma Bakanlığının, Genelkurmay Başkanlı̆̆ ve Kuvvet Komutanlıkları ile... yetki alanı kanunla düzenlenir." şeklinde mi okumalıyız? Birinci seçenek abesle iştigaldir. Zira Anayasa'nın 113. maddesinin 1. fikrasının "Bakanlıkların kurulması, kaldırllması, görevleri, yetkileri ve teşkilâtı kanunla düzenlenir." hükmü karşısında Millî Savunma Bakanlığının yetki alanının kanunla belirlenecek olmasının tekrar ifade edilmesi anlamsızdır. O halde ikinci seçenek doğru olandır. Fakat cümledeki ifade sıkıntısı da ortadadır. İkinci seçenek doğru ise düzenleme şu şekilde olmalıydı: "Millî Savunma Bakanlığının, Genelkurmay Başkanlığl ve Kuvvet Komutanlıkları ile görev ilişkileri ve bunlar karşısındaki yetki alanı kanunla düzenlenir." Düzenlemenin olması gereken şekli, mevcut düzenlemenin de anlamını ortaya koymaktadır. Dolayısıyla biz Anayasa'nın 117. maddesinin son fikrasındaki düzenlemeyi "Millî Savunma Bakanlığının Genelkurmay Başkanlığı ve Kuvvet Komutanları karşısındaki yetki alanının kanunla belirleneceği" şeklinde okuyoruz.

$\mathrm{Bu}$ tespitin önemsiz olduğu düşünülmemelidir. Zira, Millî Savunma Bakanlığının Genelkurmay Başkanlığı ve Kuvvet Komutanlıkları karşısındaki "yetki alanı"nın kanunla belirlenmesi, Millî Savunma Bakanlığının Genelkurmay Başkanlığı ve Kuvvet Komutanlıkları üzerinde sınırlı bir yetkiye sahip olacağ ${ }_{1}$ anlamına gelmektedir ${ }^{24}$. Anayasa'da bir bakanlığın adı zikredilerek tüzel kişiliği bulunmayan belirli bir idare karşısındaki "yetki alanının" kanunla belirleneceğine ilişkin benzer bir

\footnotetext{
3 Duran (1981), s. 87.
}

241961 Anayasası'nın 1971 yılında değiştirilen 110. maddesinin son fikrasının “Millî Savunma Bakanlığının görev ve yetkileri kanunla düzenlenir. Genelkurmay Başkanı, bu görev ve yetkilerden dolayı Başbakana karşı sorumludur." düzenlemesini hatırlatmakta fayda var. Görüldüğü gibi 1961 Anayasası'nın düzenlemesi "Millî Savunma Bakanlığının Genelkurmay Başkanlığı ve Kuvvet Komutanlıkları karşısındaki yetki alanı"nın kanunla belirleneceği anlamını taşıyan bir ifade içermemekteydi. 
hüküm yoktur. Anayasa'nın mahalli idareleri düzenleyen 127. maddesi İçişleri Bakanının mahalli idarelerin seçilmiş organlarını geçici olarak görevden uzaklaştırma yetkisine sahip olduğunu düzenleyerek dolaylı yoldan İçişleri Bakanının mahalli idareler üzerinde sınırlı bir yetkiye sahip olduğunu ortaya koymaktadır. Yine aynı maddede merkezî yönetimin mahalli idareler üzerinde sahip olacağı vesayet yetkisinin kanunla belirleneceğini düzenlemektedir. Anayasa'nın 130. maddesi merkezî yönetimin Yüksek Öğretim Kurumları üzerindeki yetkilerini sınırlandırmaya yönelik hükümler içermekte ve belli konuların kanunla belirleneceğini hükme bağlamaktadır. $\mathrm{Bu}$ hükümler hiç şüphesiz kamu tüzel kişiliğine sahip ve özerk idareler üzerinde merkezî yönetimin yetkilerini düzenlemek bakımından Anayasa'nın 117. maddesinin son fikrasıyla herhangi bir benzerlik taşımaz. Bununla birlikte son derece genel bir tespit yapmak gerekirse, "kanunla düzenleme" ilkesinin, Anayasa'nın özerkliğin söz konusu olduğu durumlarda başvurduğu bir yöntem olduğu söylenebilir ${ }^{25}$.

Anayasa'nın 117. maddesinin 4. fikrasında Genelkurmay Başkanının Başbakana karş1 sorumlu olduğunun belirtilmesi ve 5. fikrasında da Millî Savunma Bakanlığının Genelkurmay Başkanlığı karşısındaki "yetki alanı"nın kanunla belirleneceğinin düzenlenmesi nedeniyle Genelkurmay Başkanlığının Millî Savunma Bakanlığına bir kanunla bağlanması mümkün değildir. Bu bakımdan, ERDOĞAN'ın herhangi bir Anayasa değişikliğine gerek kalmadan da Genelkurmay Başkanının Başbakana karşı sorumlu olmasının yanında, yapılacak bir yasal düzenleme ile Millî Savunma Bakanlığına bağlanmasının mümkün olduğu yönündeki görüşüne katılmak mümkün değildir ${ }^{26}$.

Millî Savunma Bakanlığının teşkilâtı görev ve yetkileri 31.07.1970 tarih ve 1325 sayılı Millî Savunma Bakanlığ Görev ve Teşkilâtı Hakkında Kanun ile düzenlenmiştir ${ }^{27}$. Millî Savunma Bakanlığının görev ve yetkileri 1325 sayılı Kanun'un 2. maddesinde sayılmıştır. 1325 sayılı Kanun'un 2. maddesinin (a) bendine göre, Millî Savunma Bakanlığı "Millî savunma görevlerinin siyasî, hukukî, sosyal, malî ve bütçe hizmetlerini"; (b) bendine göre, "Silâhl Kuvvetlerin Bakanlar Kurulunca kararlaştırllacak savunma politikası çerçevesinde, Genelkurmay Başkanlığı tarafindan tespit olunacak ilke, öncelik ve anaprogramina göre: (1) Barışta ve savaşta asker alma hizmetlerini, (2) Silâhl, araç, gereç ve her çeşit lojistik ihtiyaç maddelerinin tedariki hizmetlerini"; (c) bendine göre ise "Malî ve mal hesap teftiş hizmetlerini" yürütmektedir. Burada dikkat çekilmesi gereken konu Millî

\footnotetext{
Gözübüyük/Akıllığlu (1992), s. 73.

Erdoğan (2002), s. 261

27 Bu Kanun, yürürlük ve yürütmeye ilişkin maddeleri dâhil 9 maddeden oluşan kısa bir kanundur.
} 
Savunma Bakanlığının "Genelkurmay Başkanlığı tarafından tespit olunacak ilke, öncelik ve anaprogramına göre" görevlerini yerine getireceğidir.

1325 sayılı Kanun'un 4. maddesine göre, "Millî Savunma Bakanı bu görevleri; müsteşarlık teşkilâtı ve Bakanlığa bağlı diğer kuruluşlar ile Kara, Deniz, Hava Kuvvetleri Komutanlıklarl vasitasiyla yerine getirir." 1325 sayılı Kanun'un "İşbirliği" başlığını taşıyan 6. maddesine göre ise "Silâhlı Kuvvetler hizmetlerini tam bir bütünlük ve beraberlik içinde yürütülmesi amacıyla Millı̂ Savunma Bakanlığı, Genelkurmay Başkanlığ ile sıkı bir işbirliği ve beraberliği içinde çalışır." "Her iki makam, görev ve yetkileri icabl Kuvvet Komutanlıklarl, diğer makamlar ve kurumlarla yaptlklart önemli ve ilgili yazışmalardan karşıllklı olarak birbirlerine bilgi verirler." Daha önce de belirttiğimiz gibi, 1325 say1lı Kanun'un 4. ve 6. maddeleri Anayasa Mahkemesinin 27.04.1971 tarihli kararıyla iptal edilmişti. Ancak, 25.04.1972 tarihli ve 1583 sayılı Kanun ile aynı hükümler, 1325 sayılı Kanun'un 4. ve 6. maddelerine aynen geri konulmuştur. 1325 say1l Kanun'un 4. ve 6. maddelerinin Anayasa Mahkemesinin iptaline rağmen 1583 sayılı Kanun ile olduğu gibi tekrar kabul edilmesinin dayanağı ise 1961 Anayasası'nın 110. maddesine 1971 değişikliklerinde eklenen 5. fikradı2 ${ }^{28}$. $\mathrm{Bu}$ fikraya göre, "Millî Savunma Bakanlığının görev ve yetkileri, Genelkurmay Başkanlığı ve Kuvvet Komutanlıklarıyla ilişkileri kanunla düzenlenir."

27.07.1967 tarih ve 926 sayılı Türk Silâhlı Kuvvetleri Personel Kanunu Millî Savunma Bakanlığına bazı yetkiler vermektedir. 926 sayılı Kanun'un 34. maddesinde Subaylığa nasıp ve subayların rütbe terfileri düzenlenmiştir. Buna göre, "Subayliğa nasip ve rütbe terfileri, ilgili Kuvvet Komutaninın (Jandarma subaylart için J.Gn. K.nın) teklifi ve Genelkurmay Başkanının lüzum göstermesi üzerine Millî Savunma Bakanı (Jandarma subayları için İçişleri Bakanı) ile Başbakanın imzalayacă̆ ve Cumhurbaşkanının onaylayacağ Kanun'un 82. maddesine göre astsubayların nasp1 ve rütbe terfileri Millî Savunma Bakanının onayına bağlıdır. Buna göre, "Astsubaylı̆̆a nasıp ve rütbe terfileri, Kuvvet Komutanının (Jandarma Astsubaylar için İçişleri Bakanı) onayı ile yapılır."

281583 sayılı Kanun'un gerekçesinde şunlar yazmaktadır: "...1325 sayılı Kanun ile Millî Savunma Bakanlığının kuvvetlerle işbirliği yapmasına imkân veren hükümlerin Anayasa Mahkemesince iptali üzerine mevcut ilişkileri yeniden düzenlemek mümkün olmamıştır. $\mathrm{Bu}$ durum üzerine iptalden önceki uygulama idarî tedbirlerle aynen muhafaza edilip yürütülmüş ve bunun bir zorunluluk olduğu gerçekleşmiştir. Hal böyle olunca yürürlükte olan şekle Anayasal dayanak aranmış ve Türkiye Büyük Millet Meclisince kabul buyurulan 22 Eylül 1971 tarih ve 1488 No. lu Kanunla 110 ncu maddeye yapılan ilâve ile Millî Savunma Bakanlığının Genelkurmay ve Kuvvetlerle ilişkiler kurması bu ilişkilerin kanunla tespiti öngörülmüştür." T.B.M.M.T.D., C. 23, S Sayısı: 496, 14.01.1972, s. 1, 2. 
Görüldüğü gibi Millî Savunma Bakanlığı görev ve yetkileri ile silâhlı kuvvetler üzerinde kayda değer bir yetkiye sahip değildir. Hatta Genelkurmay Başkanlığının bilgi ve belirlemesi dışında bir faaliyette bulunması ve işlem yapması yasal olarak mümkün değildir. 1325 sayılı Kanun'a göre Millî Savunma Bakanlığı TSK'nın lojistik birimi olarak düzenlenmiştir. ÖZAY, Genelkurmay Başkanlığı ile ilgili 1324 sayılı Kanun ve Millî Savunma Bakanlığı ile ilgili 1325 sayılı Kanun'un birbirini tamamladığını belirttikten sonra, Genelkurmay Başkanlığı hakkında şu tespiti yapmaktadır: " 'barışta ve savaşta Silâhlı Kuvvetlerin Komutanı (...)', bakanlıklar dışı ve belki de adeta, Bakanlar Kurulu üyesi olmayan ve 'birlikte' değil, sadece 'Başbakana karşı' sorumluluğu bulunan bir yetkili şeklinde düşünülmüştür." ${ }^{29}$

Genelkurmay Başkanlığının bakanlıklar karşısındaki bağımsız konumu bir tarafa, Genelkurmay Başkanı devlet protokolünde bile Bakanlardan önce gelmektedir. Söz konusu protokolün izleri her şeyden önce hukuksal düzenlemelerde kendisini gösterir. Örneğin, Anayasa'nın Millî Güvenlik Kurulunu düzenleyen 118. maddesinde MGK üyeleri sayılırken Genelkurmay Başkanı Başbakandan sonra Bakanlardan önce zikredilmektedir. $\mathrm{Bu}$ konuda, TURHAN'ın şu tespitine katılmamak olanaksızdır: Anayasa'nın 118. maddesinde Genelkurmay Başkanı, Başbakandan önce ve Bakanlardan önce sayılmıştır. Genelkurmay Başkanının görevi ne kadar önemli olursa olsun bu sıralanış biçimini kabul etmek mümkün değildir. Çünkü Genelkurmay Başkanı sivil yönetimin emrindedir ve sivil iktidarı kullanan bakanlar, Genelkurmay Başkanının atanma ve görevden alınması için Bakanlar Kurulu Kararnamelerini imzalarlar. Bakanlardan herhangi birinin imzası olmaksızın Genelkurmay Başkanı atanamaz. Durum böyle olunca, Genelkurmay Başkanının bakanlardan önce yer almasının açıklamasını yapmak güçtür ${ }^{30}$.

Özetle belirtmek gerekirse, TSK merkezî idarenin geleneksel görünümü içerisinde bir idarî hizmet olarak herhangi bir bakanlık bünyesinde örgütlenmemiştir. Genelkurmay Başkanı Başbakana karşı sorumlu kılınmıştır, fakat Başbakanlığın bağlı kuruluşu değildir. TSK bir yerinden yönetim kuruluşu da değildir. Çünkü tüzel kişiliği yoktur. Bu konum çerçevesinde, TSK genel idare teşkilâtı içerisinde ayrı bir başlık altında incelenmektedir ${ }^{31}$. DURAN Yasama, Yarg1, Yürütme ve İdareyi açıkladıktan sonra, "Türkiye Devleti konusunda ve ona özgü olmak üzere, bunlara bir de, ayrı bir varlık sayılan Silâhlı Kuvvetleri ya da Ordu cihazını

\footnotetext{
Özay, İ. H.: Günışığında Yönetim, İstanbul 2004, s. 199-201.

30 Turhan, M.: Hükümet Sistemleri ve 1982 Anayasas1, Diyarbakır 1989, s. 157-158.

31 Bkz. Gözübüyük/Akıllığlu (1992), s. 103; Yıldırım (1999), s. 73.
} 
eklemek gerekir." demektedir ${ }^{32}$. G İRITLİ/BİLGEN/AKGÜNER ve GÖZÜBÜYÜK/TAN'a göre Anayasa'daki düzenlemeler “...bir bütün olarak ele alındığında, Türk Silâhlı Kuvvetleri'nin genel yönetim içinde yer aldığ 1 ve özerk bir konumunun olduğu dikkati çeker." Ancak bu, TSK'nın sivil iktidara tâbi olmadığı anlamına gelmez ${ }^{33}$.

Genelkurmay Başkanının konumunu eleştiren TANÖR Genelkurmay Başkanının Anayasa'nın 117. maddesinde Başbakana karşı sorumlu olmasını eleştirmekte, Anayasa'nın 117. maddesinin 5. fikrasının kaldırılmasını ve 4. fikrasının da şu şekilde değiştirilmesini önermektedir: "Genelkurmay Başkanı, Millî Savunma Bakanının teklifi üzerine Cumhurbaşkanı tarafından atanır; görev ve yetkileri kanunla düzenlenir. Genelkurmay Başkanı Millî Savunma Bakanına karşı sorumludur." ${ }^{34}$

1961 Anayasası TSK'yı Türkiye idare düzeni içinde özerk bir konuma kavuşturmuştu. Benzer düzenlemeler 1982 Anayasası'nda da yer aldığı için, silâhlı kuvvetlerin idare düzeni içindeki özerk konumunun ve TSK üzerindeki sivil denetim gücünün 1944'teki seviyeyi aşamadığ 1 söylenebilir ${ }^{35}$. Genelkurmay Başkanının gerek 1961 Anayasası'nda gerekse 1982 Anayasası'ndaki konumunu demokratik ilkelerle bağdaştırmak güçtür. TANÖR'ün de belirttiği gibi, "Parlamenter rejimin özelliği, idarî hiyerarşinin gerekleri ve savunma hizmetinin niteliği açısından Genelkurmay Başkanlığının başbakanlığa değil, bakanlığa bağlı ve ona karşı sorumlu olması gerekir. Nitekim NATO ülkeleri başta olmak üzere yerleşik demokrasilerde durum böyledir." ${ }^{36}$ SOYSAL ise Genelkurmay Başkanının Başbakana karşı sorumlu tutulmasını, "askerî otoritenin sivil otoriteye tâbi olması ilkesi"nin gereğini yerine getirdiğini ve mevcut düzenlemenin parlamenter sistemin işleyişine ters düşmeyen boyutlarda olduğunu ifade etmektedir $^{37}$. Salt organik ve şeklî açıdan bakıldığında SOYSAL bir ölçüde haklı olmakla birlikte, siyasal gerçeklik bakımından Anayasa'daki düzenlemenin TSK'ya devlet düzeni içerisinde önemli ve demokratik gerekler bakımından sakıncalı bir üstünlük verdiği de gözden 1rak tutulmamalıdır. Diğer taraftan Genelkurmay Başkanının Başbakana karşı sorumlu tutulması tek başına yeterli değildir. $\mathrm{Bu}$ sorumluluğu

32 Duran (1982), s. 3.

33 Giritli/Bilgen/Akgüner: İdare Hukuku, İstanbul 2001, s. 208-209; Gözübüyük, Ş./Tan, T.: İdare Hukuku, Ankara 2004, s. 212-213.

34 Tanör, B.: Türkiye'de Demokratikleşme Perspektifleri, Tusiad Yayını, İstanbul 1997, s. 75.

35 Erdoğan (2002), s. 243. Bir görüşe göre, "1961 ve 1982 Anayasalarında yer aldığ1 şekliyle bakanlar üstü genelkurmay modeli... demokrasi kültürü gelişmemiş Türk siyasal elitine uygun görünmektedir." Özdemir (1989), s. 86.

36 Tanör (1997), s. 75.

37 Soysal (1997), s. 235, s. 237. 
somutlaştıracak yasal düzenlemeler yapılmadan askerî otoritenin sivil otoriteye tâbi olması ilkesinin gereğinin yerine getirildiğini söylemek mümkün değildir.

\section{Genelkurmay Başkanının Görev ve Yetkileri}

Genelkurmay Başkanının görev ve yetkileri genel olarak, 31.7.1970 tarihli ve 1324 sayılı Genelkurmay Başkanının Görev ve Yetkilerine Ait Kanun'da düzenlenmiştir. Bu Kanun'a göre Genelkurmay Başkanının görev ve yetkileri şunlardır:

a) "Genelkurmay Başkanı, Silâhl Kuvvetlerin savaşa hazırlanmasında; personel, istihbarat, harekât, teşkilât, ĕgitim, ögrretim ve lojistik hizmetlerine ait ilke ve öncelikler ile anaprogramların tespit eder... Lojistik tedarik hizmetleri için tespit etmiş olduğu ilke, öncelik ve anaprogramları, bu hizmetleri yürütecek olan, Millî Savunma Bakanlı̆̆ına bildirir." (1324 say1l Kanun md. 2/1 ve 2/c)

b) "Uluslararası yapılacak anlaşma ve andlaşmaların askerî yönlerinin tayininde ve uygulama esaslarınin tespitinde Genelkurmay Başkanının mütalaası alınır. Gerektiğinde bu toplantılara katılır veya temsilci gönderir." (1324 sayılı Kanun md. 3)

c) "Genelkurmay Başkanı; şahsen veya yetkili kılacağ kuruluşlarla, görev ve yetilerine ait konularda ilgili bakanllklar, daireler ve kurumlar ile doğruca yazışma yapabilir ve temaslarda bulunabilir." (1324 sayılı Kanun md. 4)

d) "Genelkurmay Başkanı, hizmetlerin yürütülmesinde Millî Savunma Bakanlı̆̆ ile işbirliği yapar." (1324 sayılı Kanun md. 6)

1324 sayılı Kanun Genelkurmay Başkanının görev ve yetkilerini genel olarak düzenlemiştir. Şüphesiz Genelkurmay Başkanının görev ve yetkileri bunlardan ibaret değildir. Diğer kanunlarda Genelkurmay Başkanına birçok görev ve yetki verilmiştir. Örneğin, Genelkurmay Başkanının askerî yargıya ilişkin yetkileri vardır. Anayasa'nın 157/2. maddesine göre, Askerî Yüksek İdare Mahkemesinin yargıç sınıfından olmayan üyeleri, her boş yer için Genelkurmay Başkanının belirleyeceği üç aday arasından Cumhurbaşkanı tarafindan seçilir. Diğer askerî hâkimler de 357 sayılı Askerî Hâkimler Kanunu'nun 16. maddesi $^{38}$ uyarınca, genel olarak subayların atanması usulüne göre, Genelkurmay Başkanının teklifi, Millî Savunma Bakanının inhası Başbakanın imzası ve Cumhurbaşkanının onayı ile atanırlar. 27.06.1972 tarihli ve 1600 sayılı Askerî Yargitay Kanunu'nun 2. maddesine göre ise "Askerî Yargıtay; Başkanlık, Başsavcıllk ve beş daire ile bu Kanunda gösterilen kurullar ve hizmet ünitelerinden teşekkül eder. Ancak iş

38 TSK Personel Kanunu'ndaki hükümlere atıf yapılmıştır. 
hacmine göre, Askerî Yargitay Genel Kurulunun teklifi ve Genelkurmay Başkanlı̆̆ının uygun görmesi üzerine Millî Savunma Bakanlığınca daire sayısı altıya kadar yükseltilebileceği gibi dörde de indirilebilir." ${ }^{39}$

17.07.1972 tarih ve 1612 sayılı Yüksek Askerî Şûranın Kuruluş ve Görevleri Hakkındaki Kanun'un 4. maddesine göre başkanlığını Başbakanın yaptığı Şûra yılda iki kez toplanır. Toplantılardan birinin ne zaman yapılacağını belirleme yetkisi Genelkurmay Başkanına aittir.

926 sayılı Türk Silâhlı Kuvvetleri Personel Kanunu'na göre Genelkurmay Başkanının disiplinsizlik nedeniyle silâhlı kuvvetlerden ayırma işlemine tâbi tutulan kişilerden hangilerinin Yüksek Askerî Şûraya sevk edileceğine karar verme yetkisi vardır. Bu konuya Yüksek Askerî Şûra incelenirken değinilecektir.

Yine 926 sayılı Kanun'un 121. maddesinin (c) bendine göre kuvvet komutanları ve Genelkurmay İkinci Başkanının atanmaları, Genelkurmay Başkanının teklifi, Millî Savunma Bakanının inhası, Başbakanın imzalayacağı ve Cumhurbaşkanının onaylayacağı kararname ile yapılmaktadır. Aynı maddenin son fikrasına göre, (c) bendinin uygulanmasında Genelkurmay Başkanının teklifi üzerine Millî Savunma Bakanı inha işlemini yapmadığı takdirde Genelkurmay Başkanı talebini yazı ile Başbakana gönderir. Başbakan kararını yazı ile Millî Savunma Bakanına ve Genelkurmay Başkanına bildirir. Başbakanın bu kararına uyulması zorunludur. Benzer bir yöntem, ileride üzerinde durulacağı gibi, İçişleri Bakanının Jandarma Genel Komutanının inha işlemini yapmaması halinde de söz konusu olmaktadır. Burada açıkça görülmektedir ki, gerek Millî Savunma Bakanının gerekse İçişleri Bakanının Genelkurmay Başkanının tercihini kabul etmemesi veya ona direnmesi olanağ kaldırılmıștır. Özellikle İçişleri Bakanı bakımından düşünüldüğünde, Bakanın siyasal sorumluluğunu taşıdığı idarî hizmeti yürütürken, teşkilâtında çalışacak üst düzey görevlinin yeri geldiğinde seçimine ilişkin takdirinin bir değeri olmalıdır ${ }^{40}$. Başbakanın Genelkurmay Başkanının tercihi yönünde karar vermesi, Bakanın, Bakanlar Kurulundaki konumunu siyasal bakımdan gözden geçirmesi sonucunu doğurabilir.

Genelkurmay Başkanının sıkıyönetim halinde de önemli yetkileri vardır. İleride de görüleceği gibi, en başta Anayasa 122/6. maddesi ile sıkıyönetim komutanlarını Genelkurmay Başkanına bağlamıştır. 1402 sayılı

Aynı Kanun'daki benzer yetkiler için bkz. md. 4, md. 5, Ek md. 3.

40 Buna rağmen, bu düzenlemelerin 3056 sayılı Başbakanlık Teşkilâtı Hakkında Kanun Hükmünde Kararnamenin Değiştirilerek Onaylanması Hakkında Kanun'un 4. maddesinin ilk fikrasındaki "Başbakan, ..., bakanlıkların ... en üst amiridir." düzenlemesiyle tutarlılık içinde olduğu düşünülebilir. 
Sıkıyönetim Kanunu'nda Genelkurmay Başkanına ciddî yetkiler verilmiştir. 1402 sayılı Kanun'un 5. maddesine göre sıkıyönetim komutanları, Genelkurmay Başkanının teklifi üzerine Millî Savunma Bakanının inhası Başbakanın imzalayacağı ve Cumhurbaşkanının onaylayacağı bir kararname ile atanır. Yine 1402 sayılı Kanun'un 11/6. maddesine göre Sikıyönetim Askerî Mahkemelerine yeteri kadar subay üye Genelkurmay Başkanının teklifi üzerine askerî hâkim subayların tayini usulüne göre atanır. 1402 sayılı Kanun'un 21. maddesi, Kanun'da geçen suçlardan dolay1 yargılanabilecek olan general ve amiraller hakkında kovuşturma yapılabilmesini Genelkurmay Başkanının iznine tâbi tutmuştur. 1402 sayılı Kanun'un 24. maddesine göre ise "Savaş halinde Sikıyönetim ilan edilmemiş olsa dahi, Genelkurmay Başkanının teklifi üzerine Bakanlar Kurulunca tespit ve ilan edilen bölgedeki komutanlardan, Genelkurmay Başkanının görevlendirdiği bir komutan bu kanunun üçüncü maddesinde yazılı tedbirleri almaya ve uygulamaya yetkilidir." Yine 1402 sayılı Kanun'un 5. maddesinin 1. fikrasına göre, çeşitli bölgelerde sıkıyönetim ilân edilmişse koordinasyonu Genelkurmay Başkanı sağlar.

Genelkurmay Başkanlığıyla ilgili çok ilginç bir başka hüküm 2954 sayılı Radyo ve Televizyon Kanunu'nun 31. maddesinde yer almıştır. Buna göre, "Radyo ve Televizyon yayıları, yayından önce ayrica Türkiye-Radyo Televizyon Kurumu dışından hiçbir kişi veya kuruluş tarafindan denetlenemez. Ancak, Türk Silâhlı Kuvvetleri ile ilgili yayınlar hakkında Genelkurmay Başkanlığının olumlu görüşü alınır." Bu düzenlemenin birinci cümlesi açıtır ki bir sansür yasağını ifade etmektedir. İkinci cümle ise sansür yasağının istisnasını, diğer bir deyişle Genelkurmay Başkanlığının Türk Silâhlı Kuvvetleri ile ilgili yayınlarda sansür yetkisini düzenlemektedir. $\mathrm{Bu}$ tür bir ilişki biçimine gerçekten ihtiyaç duyulsa bile bunun sıkıyönetim ve savaş hali gibi olağanüstü durumlara özgülenmesi ve Genelkurmay Başkanlığının "olumlu görüşü" yerine "görüşü" alınır şeklinde düzenlenmesi yerinde olurdu.

Bunlar dışında çeşitli yasalarda Genelkurmay Başkanına birçok görev ve yetki verilmiştir ${ }^{41}$. Burada son olarak Genelkurmay Başkanlığının yürürlükten kaldırılan ilginç bir yetkisini hatırlamakta fayda vardır. Bunlardan birincisi Anayasa'nın 131. maddesinin 2. maddesi uyarınca

41 Bkz. 9.7.1982 tarihli ve 2692 sayılı Sahil Güvenlik Komutanlığı Kanunu md. 2/(a), md. 3, md. 6, md. 8, md. 18, md. 23; 10.3 .1983 tarihli ve 2803 sayıl Jandarma Teşkilât, Görev ve Yetkileri Kanunu md. 5, md. 7/(c), md. 8, md. 13, md. 14/(b)(c), md. 19; 01.11.1983 tarihli ve 2937 sayılı Devlet İstihbarat Hizmetleri ve Millî İstihbarat Teşkilâtı Kanunu md. 4/(a)(b)(e); 17.11 .1983 tarihli ve 2955 sayılı Gülhane Askerî Tıp Akademisi Kanunu md. 5/2, 5/(c)(d), md. 9/1, md. 12/1,2, md. 13/(a), md. 14/2, md. 16/1, md. 19/1, md. 20/1,2, md. 21/1, md. 26, md. 27/1, md. 28/1, md. 29/(b), md. 34, md. 37; 4.11.1983 tarihli ve 2941 sayılı Seferberlik ve Savaş Hali Kanunu md. 6, md. 7. 
Genelkurmay Başkanının Yüksek Öğretim Kuruluna üye seçme yetkisiydi. 2575 sayılı Yükseköğretim Kanunu'nun 6. maddesine göre Genelkurmay Başkanlığı Yükseköğretim Kuruluna bir üye seçme yetkisine sahipti. Genelkurmay Başkanının Yükseköğretim Kuruluna üye seçme yetkisi Anayasa'nın 131. maddesinin 2. fikrasında 07.05.2004 tarih ve 5170 sayılı Kanun ile yapılan değişikliğin ardından kaldırılmıştır ${ }^{42}$.

\section{B) ÖZEL STATÜLÜ İKİ KURULUŞ: JANDARMA ve SAHİL GÜVENLİK KOMUTANLIĞI}

Jandarma ve Sahil Güvenlik Komutanlığı, kolluk görevi yürütmesine rağmen TSK'nın birimleridir. TSK'nın aslî görevinin millî savunma olması karşısında Jandarma ve Sahil Güvenlik Komutanlığının idarî teşkilât içerisindeki yeri özellik arz etmektedir.

04.01.1961 tarihli ve 211 sayılı İç Hizmet Kanunu'nun 1. maddesi TSK'yı tanımlarken Jandarmayı da bu tanımın içine dâhil etmiştir. Kuvvet komutanlıklarının (kara, hava, deniz) ayrı bir yasası bulunmazken, jandarmanın gösterdiği özellik nedeniyle ayrı bir teşkilât, görev ve yetki kanunu vardır.

10.3.1983 tarihli ve 2803 say1lı Jandarma Teşkilât, Görev ve Yetkileri Kanunu'nun 3. maddesi jandarmayı "emniyet, asayiş ve kamu düzeninin korunmasını sağlayan silâhll, askerî bir güvenlik ve kolluk kuvveti" olarak tanımlamıştır. 3201 sayılı 04.06.1931 tarihli Emniyet Teşkilâtı Hakkında Kanun'un 3. maddesi de jandarmayı genel kolluk olarak tanımlamıştır.

Jandarma kolluk görevi gördüğü için bir taraftan İçişleri Bakanlığı ile bir taraftan da Genelkurmay Başkanlığı ile ilişkilendirilmiştir. 14.2.1985 tarihli ve 3152 sayılı İçişleri Bakanlığının Teşkilât ve Görevleri Hakkında Kanun'un 29. maddesi Emniyet Genel Müdürlüğü, Jandarma Genel Komutanlığı ve Sahil Güvenlik Komutanlığını İçişleri Bakanlığının bağlı kuruluşu olarak saymıştır. 2803 sayılı Kanun'un 4. maddesine göre, "Jandarma Genel Komutanlı̆̆, Türk Silâhlı Kuvvetlerinin bir parçası olup, Silâhlı Kuvvetler ile ilgili görevleri, ĕgitim ve ögretim bakımından Genel Kurmay Başkanlı̆̆ına, emniyet ve asayiş işleriyle diğer görev ve hizmetlerin ifası yönünden İçişleri Bakanlı̆̆ına bağlıdır. Ancak Jandarma Genel Komutanı, Bakana karşı sorumludur." 2803 sayılı Kanun'un 14. maddesinin (c) bendinde "Jandarma Genel Komutaninin atanmasi Genelkurmay Başkanının teklifi, İçişleri Bakanının inhası, Başbakanın imzalayacă̆ı ve Cumhurbaşkanının onaylayacağl müşterek kararname ile yapılır." denmektedir. Yine aynı maddeye göre Genelkurmay Başkanının teklifi

42 Anayasa değişikliğinin paralelinde 14.07.2004 tarih ve 5218 sayılı Kanun ile, 2575 sayılı Yükseköğretim Kanunu'nun 6'ncı maddesinde değişiklik yapılarak Genelkurmay Başkanlığının Yüksek Öğretim Kuruluna üye seçme yetkisi yasal olarak da kaldırılmıştır. 
üzerine, İçişleri Bakanı inha işlemini yapmadığı takdirde, Genelkurmay Başkanı talebini yazı ile Başbakana gönderir. Başbakan kararını yazı ile İçişleri Bakanına bildirir ${ }^{43}$.

Subay Sicil Yönetmeliği’nin ${ }^{44}$ 6/5. maddesine göre Jandarma Genel Komutanının birinci sicil üstü Genelkurmay Başkanıdır.

10.06.1949 tarihli ve 5442 sayılı İl İdaresi Kanunu'nun 11. maddesine göre ildeki jandarmanın amiri validir ve jandarma valinin emri altındadır.

Jandarmanın sıkıyönetim, seferberlik ve savaş halindeki kullanımı hakkında 2803 sayılı Kanun'un 8. maddesi bir düzenleme getirmiştir. Buna göre, "Jandarma birlikleri; Genelkurmay Başkanlığınca lüzum görülen hallerle sıkıyönetim, seferberlik ve savaş hallerinde gerekli olan bölümü ile Kuvvet Komutanlıklarl emrine girer, kalan bölümü ile Jandarma Genel Komutanliğl emrinde normal görevlerine devam eder."

2803 say1lı Kanun'un 10. maddesine göre, jandarmanın genel olarak görev ve sorumluluk alanı, polisin görev alanının dışında olup, bu alanlar il ve ilçe belediye hudutları haricinde kalan veya polis teşkilâtı bulunmayan yerlerdir.

2803 sayılı Kanun'un 7. maddesinde Jandarmanın görevleri şu şekilde sayılmıştır: "a) Mülki görevleri; Emniyet ve asayiş ile kamu düzenini sağlamak, korumak ve kollamak, kaçakçılığı men, takip ve tahkik etmek, suç işlenmesini önlemek için gerekli tedbirleri almak ve uygulamak, ceza infaz kurumları ve tutukevlerinin dış korunmalarını yapmak. b) Adli görevleri; İslenmiş suçlarla ilgili olarak kanunlarda belirtilen işlemleri yapmak ve bunlara ilişkin adli hizmetleri yerine getirmek. c) Askerî görevleri; Askerî kanun ve nizamların gereği görevlerle Genelkurmay Başkanlığınca verilen görevleri yapmak."

Genelkurmay Başkanının 2803 sayılı Kanun'un 7. maddesinin (c) bendinde düzenlenen yetkisi, Jandarma Genel Komutanlığını iki başlı bir konuma sokmaktadır. Jandarma Genel Komutanının birinci sicil üstünün Genelkurmay Başkanı olması bu durumu pekiştirmektedir. Mevcut düzenlemeler dikkate alındığında Jandarmanın askerî kimliğinin ön planda olduğu açıktır.

Sahil Güvenlik Komutanlığı da Jandarma Genel Komutanlığıyla hemen hemen aynı statüde ve benzer düzenlemelerle kurulmuş ve görevlendirilmiştir. 09.07.1982 tarihli ve 2692 sayılı Sahil Güvenlik Komutanlığı Kanunu'nun 2/2. maddesine göre "Bu Komutanlık, Türk Silâhlı Kuvvetleri kadro ve kuruluşu içersinde olup, barışta görev ve hizmet

$43 \mathrm{Bu}$ konu yukarıda tartışıldı.

44 RG., 27.12.1998, S. 23566. 
yönünden İçişleri Bakanlı̆̆ına bağlldır." Yine aynı maddeye göre olağanüstü hallerde Genelkurmay Başkanının isteği üzerine sahil güvenlik birimleri kısmen veya tamamen Deniz Kuvvetleri Komutanlığının emrine girer. Savaş halinde ise sahil güvenlik birimleri tümü ile Deniz Kuvvetleri Komutanlığının emrine girer.

Sahil Güvenlik Komutanlığının görev alanları, üsleri, yerleşme yerleri Genelkurmay Başkanının görüşü alınarak İçişleri Bakanlığınca belirlenir (2692 sayılı Kanun md.3). Komutanlığın temel görevi karasularını korumak ve karasularında güvenliği sağlamaktır (2692 sayılı Kanun md.4).

Sahil Güvenlik Komutanlığında görev yapacak olan personel Deniz Kuvvetleri Komutanlığından temin edilir (2692 sayılı Kanun md.7). Sahil Güvenlik Komutanlığına, tümamiral rütbesindeki subay, Deniz Kuvvetlerinin lüzum göstermesi, Genelkurmay Başkanının teklifi, İçişleri Bakanının inhası üzerine Başbakanın imzalayacağı ve Cumhurbaşkanının onaylayacağı kararname ile atanır (2692 sayılı Kanun md.8). Sahil Güvenlik Komutanının birinci sicil üstü Genelkurmay Başkanıdır (2692 sayılı Kanun md. 18/1).

Gerek jandarma genel komutanı gerekse sahil güvenlik komutanlarının birinci sicil üstlerinin Genelkurmay Başkanı olması, söz konusu birimlerin sivil iktidardan daha çok Genelkurmay Başkanına bağlı olduğu izlenimini doğurmaktadır.

Özellikle jandarma bakımından değerlendirildiğinde, TSK'nın ülkenin çok büyük bir bölümünde kolluk yetkisine sahip olmak bakımından son derece güçlü bir konumda bulunduğu söylenebilir. Türkiye'de jandarmanın yaygın olarak kullanılmasının sebebi kırsal alanın genişliği ve bu alanlarda polis teşkilâtının kurulamamış olmasıdır.

Jandarma kolluk görevi yürüttüğü için hukukla daha iç içedir. Kolluğun kuvvetli bir hukuk bilgisine sahip olması gerekir. Ancak jandarma personelinin çok büyük bir kısmı zorunlu askerliğini yapan erlerden oluşmaktadır. $\mathrm{Bu}$ durumun kolluk işlevinin sıhhati bakımından belli şüpheleri beraberinde getirmesi kaçınılmazdır. Türkiye'de kolluk işlevine ilişkin zafiyetlerden söz edilirken jandarmanın uygulamaları neredeyse hiç gündeme gelmemektedir.

C) SIVIL VE ASKERLERDEN OLUŞAN KURULLAR

\section{Yüksek Askerî Şûra (Y A Ş )}

\section{a) Kuruluş ve İşleyiş}

Yüksek Askerî Şûra (YAŞ), 17.07.1972 tarih ve 1612 sayılı Yüksek Askerî Şûranın Kuruluş ve Görevleri Hakkında Kanun ile kurulmuştur. 1612 sayılı Kanun'un 1. maddesine göre, YAŞ sadece barış zamanlarında görev yapar. 
YAŞ'ın iki sivil üyesi olan Başbakan ve Millî Savunma Bakanı dışındakilerin hepsi askerdir. YAŞ'ın asker üyeleri Genelkurmay Başkanı, Kuvvet Komutanları, Ordu Komutanları, Jandarma Genel Komutanı, Donanma Komutanı ile Silâhlı Kuvvetler kadrolarında bulunan diğer orgenerallerdir. Jandarma teşkilâtının personel işılerine yönelik bazı kararların YAŞ'ta alınması nedeniyle İçişleri Bakanının da YAŞ'ta bulunması gerekirdi.

1612 sayılı Kanun'un 2. maddesine göre YAŞ'ın başkanlığını Başbakan yürütür. Başbakan olmadığında başkanlığı Genelkurmay Başkanı yerine getirir. Millî Savunma Bakanının bulunduğu bir kurulda Genelkurmay Başkanının başkanlığı üstlenmesi TSK'nın idarî teşkilât içindeki "sıra dışı" konumunun önemli göstergelerinden biri olsa gerek.

YAŞ her yıl olağan olarak yılda iki kez toplanır. Toplantılardan biri Ağustos ayının ilk haftası ikincisi ise Genelkurmay Başkanının belirleyeceği bir zamanda yapılır. Yine Genelkurmay Başkanının isteği üzerine yıl içinde ayrıca toplanılabilir. YAŞ toplantıları gizli olarak yapılır ve kararlar toplantıya katılan üyelerin salt çoğunluğu ile alınır. Görüşmelerin ve alınan kararların yayınlanması yasaktır. Nelerin açıklanabileceğine YAŞ karar verir (1612 say1l1 Kanun md. 4, 5, 8)

\section{b) Görev ve Yetkiler} Bunlar:

1612 sayılı Kanun'un 3. maddesi YAŞ'ın görevlerini saymıştır.

a) "Genelkurmay Başkaninca hazırlanan askerî stratejik anafikrin (Konseptin) tespiti ve gerektiğinde yeniden gözden geçirilmesi hususlarında görüş bildirmek;"

b) " Silâhlı Kuvvetlerin anaprogram ve hedefleri ile ilgili konularda görüş bildirmek;"

c) "Silâhlı Kuvvetlerle ilgili olup önemli görülen kanun, tüzük ve yönetmelik taslaklarını inceleyip görüs bildirmek;"

d) "Başbakan, Genelkurmay Başkanı veya Millî Savunma Bakanının lüzum gördükleri hallerde Silâhlı Kuvvetlerle ilgili diğer konular hakkında görüş bildirmek."

Burada sayılan görevler görüş bildirmek şeklinde düzenlenmiştir. YAŞ 1612 sayılı Kanun'un 3. maddesinde sayılan görevleri itibariyle Başbakan, Millî Savunma Bakanı ve Genelkurmay Başkanına görüş bildiren yardımcı bir idarî kurul niteliğindedir.

Bununla birlikte, 27.07.1967 tarih ve 926 sayılı Türk Silâhlı Kuvvetleri Personel Kanunu'nda YAŞ'a TSK personeli hakkında icraî kararlar almaya yönelik ciddî yetkiler verilmiştir. Esasen YAŞ'ın en önemli özelliği, TSK personeli hakkında, TSK personel yapısının özelliği gereği, 
terfi, emeklilik, disiplin işlerine yönelik kararlar veren uzmanlık kurulu olmasıdır. Bu yönü ile Hâkimler ve Savcılar Yüksek Kuruluna benzetilebilir. Anayasa'nın 125. maddesinin 2. fikrası YAŞ kararlarını yargı denetiminin dışında tuttuğu için YAŞ'a TSK Personel Kanunu ile verilen yetkiler daha da önem kazanmış ve tartışmalı hale gelmiştir.

926 sayılı TSK Personel Kanunu YAŞ'a silâhlı kuvvetlerin yüksek rütbeli subaylarının terfileri, emeklilikleri, kadroları ve yükseltilmelerine ilişkin kararlar alma yetkisi vermektedir (md. 41, md. 44, md. 47, md. 54, md. 49/c-d).

Anayasa'nın 125/2. maddesine göre YAŞ kararlarına karşı dava açmak mümkün değildir. Bu konuya "yargısal denetim" başlığı altında tekrar değinilecektir. Ancak, YAŞ kararlarına karşı yarg1 yolunun kapatılmış olmasının, TSK'nın personel rejimini tamamen kendi içinde yürüttügü kapalı bir alan haline getirdiğini belirtelim. Yine bu konuyla ilgili bir başka soruna burada değinmek gerekir. 926 sayılı TSK Personel Kanunu'nun 50/c maddesi subayların, 94/b maddesi de astsubayların disiplinsizlik nedeniyle emekliye sevk edilmesini düzenlemektedir. Söz konusu maddelerde personelin disiplinsizlik nedeniyle ordudan ilişkilerinin kesilmesine ilişkin usulü belirleme yetkisi Genelkurmay Başkanının takdirine bırakılmıştır. Disiplinsizlik sorunu bulunan personel Genelkurmay Başkanının kararıyla YAŞ'a sevk edilebileceği gibi, gerekli işlemlerin yapılması için kuvvet komutanlıklarına da sevk edilebilir. Eğer emekliye ayırma işlemi kuvvet komutanlıklarınca yapılmışsa, ilgili, yargı yoluna başvurabilecektir. Ancak, işlemi YAŞ yapmış ise Anayasa'nın 125/2. maddesi gereğince yargı yoluna başvurmak mümkün olmayacaktır. İlgilinin Genelkurmay Başkanının kararıyla yargı yoluna başvurma hakkının engellenebilecek olmasını hukuk devletinin bilinen ilkeleriyle bağdaştırmak güçtür. Bu nedenle Kanun'un anılan hükümlerinin Anayasa'ya aykırı olduğu düşünülebilir ${ }^{45}$.

Askerî Yüksek İdare Mahkemesi (AYIMM) de bir kararında konuya değinmiş ve şu kararı vermiştir:

Davacı tarafından "...926 Sayılı Kanunun Yüksek Askerî Şûra'ya ilişkin idarî işlem niteliğinde görev vermiş olmasının, ayrıca Genelkurmay Başkanının, mutlak fakat ölçü, neden ve sinırları belirtilmemiş takdir yetkisi ile donatılip kişilerin hak arama hürriyetlerini yok etme sonucunu doğuracak şsekilde ayırma işlemlerini Yüksek Askerî Şûra gündemine alınmasını sağlamasının Anayasaya aykırı düştüğü ileri sürülmektedir."

"Gerçekten, Sicil Yönetmeliğinin ayırma nedenleri olarak belirlediği haller yönünden aynı konumda bulunan Türk Silâhlı Kuvvetlerinin iki personelinden Kuvvet Komutanlı̆̆ınca tesis edilen ayırma işlemi ile ilişiğin

45 Aynı yönde Erdoğan (2002), s. 253. 
kesilmesi durumunda yargisal korunmadan yararlanabilmekte, iddialarin hukuken geçerli görülmesi halinde yargl kararları ile görevine dönebilmekte, en azından hakkindaki ayırma işleminin yargı denetiminden geçirilmesi olanağı bulunmakta iken, aynı konumdaki diğeri Yüksek Askerî Şûra kararı ile ayrılmış ise tümüyle yargı hakkından yoksun kalmaktadır."

"Ancak, 926 Sayılı Kanunun Yüksek Askerî Şûra kararı ile ayırma işleminin yapılabileceğine ilişkin hüküm, 926 Sayılı Kanunun 94 ncü maddesinin (b) bendine (subaylar için 50 nci maddenin (c) bendine) 29 Temmuz 1983 tarih ve 2870 Sayll Kanunla ilave edilmis olup Anayasaya aykırılı̆̆ ileri sürülemeyen hükümlerdendir."46 Anayasa'nın geçici 15. maddesinin son fikrası yürürlükten kalktığına göre 926 sayılı TSK Personel Kanunu'nun ilgili maddelerinin Anayasa'ya aykırılı̆̆ 1 ileri sürülebilir. Genelkurmay Başkanının ilgili hakkında karar verilmek üzere YAŞ’a ya da kuvvet komutalığına sevk işlemi iptal davasına konu edilebilecek idarî bir işlemdir.

\section{Millî Güvenlik Kurulu (MGK)}

TSK ile ilgili tartışmalarda Millî Güvenlik Kurulu her zaman önemli bir yere sahip olmuştur. Bilindiği gibi MGK'nın üyeleri asker ve sivil kişilerdir. Genelkurmay Başkanı ve kuvvet komutanlarının kurulun MGK'da oy kullanma yetkisine sahip olmaları MGK'yı başlıklarımız arasına almayı kaçınılmaz kılmaktadır. "Millî güvenlik" kavramı "millî savunma" kavramını da içeren kapsayıcı bir kavramdır. MGK'ye ilişkin tartışmalar "millî savunma" kavramı çerçevesinde TSK'nın işlev ve etkinliğinden bağımsız değildir. Bu bakımlardan MGK'nın yapısı ve işleyiş̧i TSK'nın sivil otorite karşısındaki pozisyonunu belirlemek bakımından önem taşımaktadır.

\section{a) Millî Güvenlik Kurulunun Tarihsel Gelișimi}

MGK, bu isimle ve bir Anayasal organ olarak ilk defa 1961 Anayasası'nda idare düzeni içerisine girmişti. Ancak, 1961 Anayasası öncesinde de bu kurulun benzeri bir kurul sistem içerisinde mevcuttu. $\mathrm{Bu}$ kurul Millî Savunma Yüksek Kurulu (MSYK) adını taşıyordu. MSYK, 30.05.1949 tarihli ve 5399 sayılı Millî Savunma Yüksek Kurulu Kanunu ile kurulmuştu. MSYK'nın tabii başkanı Cumhurbaşkanıydı. MSYK, Başbakanın başkanlığı altında ve onun teklifi ile Bakanlar Kurulu tarafından seçilen Bakanlar, Millî Savunma Bakanı ve Genelkurmay Başkanı ile toplanırd1.

MSYK'nın görevleri şunlardı: Bakanlar Kurulu tarafindan takip edilecek millî savunma politikalarının esaslarını hazırlamak. Topyekûn millî seferberlik planını barışta hazırlamak ve gerektiğinde tam olarak

46 AYiM, 1.D., E. 1997/147, K. 1998/200, KT. 22.1.1998, AYİM Dergisi, S. 12, s. 1140 1142 . 
uygulanmasını sağlamak. Ülke savunmasıyla ilgili işlerden Başbakanın lüzum gösterdiklerini inceleyerek görüşünü bildirmek.

MSYK kararlarından doğrudan doğruya icra edilecek olanlar, Başbakan tarafindan ilgili yerlere tebliğ olunurdu. Bakanlar Kurulu kararını gerektirenler Bakanlar Kuruluna sunulurdu. Millî Savunma Yüksek Kurulu en az ayda bir kez toplanırdı.

Başbakanın direktiflerine göre MSYK çalışmalarını hazırlamak ve her türlü yazı işlerini yürütmek üzere bir Millî Savunma Yüksek Kurulu Genel Sekreterliği vardı. Genel sekreter Genelkurmay Başkanının görüşü alınarak Millî Savunma Bakanınca yapılacak teklif üzerine MSYK tarafindan tespit edilirdi ${ }^{47}$.

1949 yılından beri Türkiye idare düzeni içinde yer alan MSYK, 1961 Anayasası'nda Millî Güvenlik Kurulu adıyla anayasal kuruluş halini almıştır. MSYK ile gerek 1961 Anayasası'nda gerekse 1982 Anayasası'nda yer alan MGK arasında kuruluş, yetki ve görevler bakımından benzerlikler gözlenir. Fakat, MSYK'nın sonraki ikisinden çok önemli farkları da vardı. TANÖR'e göre, "MSYK'nun üç özelliği demokratik anlayış açısından takdire değer sayılmalıdır: Anayasal değil yasal düzeyde olması, adının 'Millî Güvenlik' değil çok daha sınırlı bir işlev olan 'Millî Savunma' olması ve barışta bir tek asker üyenin (Genelkurmay Başkanı) katılımına açık olması. 1961'de getirilen düzenleme kökünü buradan almış gibi görünse de, özü bakımından çok farklıdır." ${ }^{48}$

1961 Anayasası'nın 111. maddesinde MGK şu şekilde düzenlenmişti:

"Millî Güvenlik Kurulu, kanunun gösterdiği Bakanlar ile Genelkurmay Başkanı ve Kuvvet temsilcilerinden kuruludur."

"Millî Güvenlik Kuruluna Cumhurbaşkanı başkanlık eder; bulunmadiğl zaman, bu görevi Başbakan yapar."

"Millî Güvenlik Kurulu, millî güvenlik ile ilgili kararların alınmasında ve koordinasyonun sağlanmasında yardımcılık etmek üzere gerekli temel görüşleri Bakanlar Kuruluna bildirir."

Burada dikkati çeken ilk konu MGK'nin kompozisyonudur. MGK'deki Asker üyelerin sayısı dörttü. Sivil üyelerin kimler olacağı ise Kanun'a bırakılmıştı. 11.12.1962 tarihli ve 129 sayılı Millî Güvenlik Kurulu Kanunu'na göre Devlet Bakanı Başbakan Yardımcıları, Millî Savunma, İçişleri, Dışişleri, Maliye, Ulaştırma ve Çalışma Bakanları ve gündemle ilgili

47 Derbil, S.: İdare Hukuku, Ankara 1959, s. 632; Aybay, R.: "Millî Güvenlik Kavramı ve Millî Güvenlik Kurulu”, A.Ü.S.B.F.D., C. XXXIII, S. 1-4, 1979, s. 73; Tanör (1997), s. 76; Özdemir (1989), s. 94-97.

48 Tanör (1997), s. 76. 
olarak Başbakanın çağıracağı diğer bakanlar da kurul üyesiydi ${ }^{49}$. Bu düzenlemeye göre MGK'nin üye sayısı değişkenlik arz etmekteydi. Buradaki önemli bir nokta ise, sivil üyelerin sayılarının, asker üyelerden daha fazla olmasiydi.

129 sayılı Kanun'a göre MGK'nın görev, yetki konuları ve çalışma usulleri üzerinde uzun uzun durmayacağız. Esasen söz konusu görev ve yetki konuları 1982'den sonraki düzenlemede genişlemişse de, hemen hemen aynı çizgide yer almıştı.

1961 Anayasası'nda 12 Mart müdahalesinden sonra gerçekleştirilen 1971 değişikliklerinde MGK da ele alınmıştı. Söz konusu değişikliklerle, kurulun oluşumunda "kuvvet temsilcileri" yerine "kuvvet komutanları" ifadesi getirilmişti. Aslında bu değişiklik 129 sayılı Kanun'daki düzenlemenin Anayasa'ya yansıtılmasından başka bir şey değildi. Daha önemli değişiklikler de yapılmıştı. 1961 Anayasası'nın 111. maddesinin ilk şeklinde MGK'nın görüşlerini Bakanlar Kuruluna "bildirmesi" söz konusu iken, yapılan değişiklikle "bildirme" yerine "tavsiye etme" ifadesi konulmuştu. 1971 değişiklikleriyle "bildirme" sözcügü yerine "tavsiye" sözcüğü getirilerek MGK kararlarına daha fazla ağırlık verilmesi yönünde bir adım atılmış oldu ${ }^{50}$. Şöyle ki, "görüş bildirme" alışılmış ve yerleşmiş anlamına göre bağlayıcı gücü olmayan "istişare" ya da "danışma" da bulunmaktan ibarettir ve genellikle yetkili organ ve makamın isteği üzerine verilir. "Tavsiye" ise, en azından eşitlerin birbirine verdiği direktif anlamını içerir ve muhatap olanın takdirini az çok kısıtlar. Bu nedenle MGK kararlarının hukuksal değilse bile siyasal ve moral etkilerinin bulunduğu ifade edilmiştir ${ }^{51}$.

Burada SOYSAL'in bir tespitini aktarmakta fayda vardır. SOYSAL, 1961 Anayasası döneminde, siyasal yaşamın bunalımlı dönemlerinde yapılan MGK toplantılarının "Bakanlar Kuruluna bildirilecek" görüşlerin oluştuğu bir yer olmaktan çıktığını ve gerçekte Bakanlar Kurulu kararlarının yüksek rütbeli komutanlarca belirlendiği bir üst kabine niteliği kazandığını ifade etmektedir ${ }^{52}$.

DURAN, 1961 Anayasası dönemindeki MGK hakkında şu genel değerlendirmeyi yapmıştır: "Millî Güvenlik Kurulu, II. Cumhuriyet rejiminin askerî bir harekât sonucunda belirlenmiş olduğunu en iyi kanıtlayan anayasal müessesedir. Millî Güvenlik Kurulu, Anayasa'da

\footnotetext{
Aybay (1979), s. 76.

Soysal (1997), s. 235.

Duran (1982), s. 130.

Soysal (1997), s. 235. DURAN da "Millî Güvenlik Kurulu, II. Cumhuriyet rejiminde kamusal yaşamın en güçlü etkeni niteliğini kazanmıştır." demektedir. Duran (1982), s. 131.
} 
öngörülüp esasları konulmuş, görev alanı belirsiz ve geniş kapsamlı, yetkisi direktif niteliğinde ve bir bakıma siyasî bir organ durumundadır. Özellikle 1971 Anayasa değişikliklerinden sonra, bu durum daha da belirgin biçimde ortadadır." ${ }^{53}$ DURAN'ın yaptığ 1 bu genel değerlendirme birçok açıdan bugün de geçerlidir.

b) 1982 Anayasası'nda Millî Güvenlik Kurulu ve Millî Güvenlik Kuruluna Yeni Bir Görünüm Kazandırma Çabaları

1982 Anayasası'nda MGK, 1961 Anayasası'ndakine oranla daha ayrıntılı bir biçimde düzenlenmiştir. MGK'ya ilişsin tartışmalar geçmişten bu güne canlılığını sürdürmektedir. MGK'nın sistem içindeki etkinliğine yönelik eleştirileri bertaraf etmek amacıyla Anayasa'nın 118. maddesinde ve 09.11.1983 tarihli, 2945 say1lı Millî Güvenlik Kurulu ve Millî Güvenlik Kurulu Genel Sekreterliği Kanunu'nda önemli değişiklikler yapılmıştır. Değişiklikten önceki düzenlemelerle birlikte mevcut durumu inceleyip değişikliklerin amacı ve bu amacın gerçekleşip gerçekleşmediğini inceleyelim.

\section{c) Millî Güvenlik Kurulunun Oluşumu ve İşleyişi}

MGK'nın oluşum biçimi, TSK'nın siyasal tarihimizdeki yeri ve MGK'nın siyasal sistemin işleyişi üzerindeki etkileri göz önünde bulundurulduğunda önem taşıyan bir konudur. Anayasa'nın 118. maddesinin 1. fikrasının ilk şekline göre MGK Cumhurbaşkanı, Başbakan, Millî Savunma, İçişleri, Dışişleri Bakanları ve Genelkurmay Başkanı, Kara, Hava, Deniz Kuvvetleri Komutanları ile Jandarma Genel Komutanından oluşmaktaydı. Kurul üyelerinin beşi sivil, beşi de asker üyeydi. 1961 Anayasası'nda, bundan farklı olarak, kurul üyelerinin kimler olabileceği sınırlı bir şekilde belirlenmemişti. Yukarıda da belirtildiği gibi, 1961'deki düzenlemede konu yasa koyucunun takdirine bırakılmıştı ve sivil üyelerin sayısı açık olarak fazlaydı.

Yöneltilen eleştiriler nedeniyle olsa gerek, MGK'nın oluşum biçimi Anayasa'da yapılan değişikliklerle yeniden düzenlenmiştir. Anayasa'nın 118. maddesinin 1. fikrasinın 03.10.2001 tarih ve 4709 sayılı Kanun'un 32. maddesiyle değiştirilmesinin ardından Başbakan yardımcıları ve Adalet Bakanı da MGK üyesi olmuştur. Bu değişiklikle MGK sivil üyelerin sayıca ağırlıkta olduğu bir kurul halini almıştır. Bu değişikliğin MGK'ye olumlu bir "görünüm" kazandırdığ 1 şüphesizdir.

Burada dikkati çeken bir konu Jandarma Genel Komutanının MGK üyesi olmasıdır. Daha önce de açıklandığı gibi, Jandarma Genel Komutanlığının esas işlevi İçişleri Bakanlığına bağlı olarak "kolluk"tur. Jandarmanın işlevinin Polisin işlevinden bir farkı yoktur. Hem Emniyet

53 Duran (1982), s. 128. 
Genel Müdürlüğü hem de Jandarma Genel Komutanlığı hizmet bakımından İçişleri Bakanlığına bağlıyken Jandarma Genel Komutanının MGK'da bulunmasını gerektiren zorunlulukların, Emniyet Genel Müdürü için niçin düşünülmediğini açıklamak zordur ${ }^{54}$.

2945 sayılı Millî Güvenlik Kurulu ve Millî Güvenlik Kurulu Genel Sekreterliği Kanunu'nun 3. maddesine göre, gündemin özelliği gereği MGK'ya ilgili bakan veya ilgili kişiler çağrılabilir ve Millî Güvenlik Kurulu Genel Sekreteri her toplantıya katılır. Gündemin özelliğine göre çağrılanlar alınacak kararlara katılamaz; sadece istenen görüşleri bildirirler. Millî Güvenlik Kurulu Genel Sekreteri de her toplantıya katılmasına rağmen alınacak kararlarda oy kullanma yetkisine sahip değildir.

Anayasa'nın 118. maddesine göre, MGK Cumhurbaşkanının başkanlığında toplanır. Cumhurbaşkanının MGK toplantısına katılmadığ 1 durumlarda başkanlığı Başbakan üstlenir. Kurulun gündemi Başbakan ve Genelkurmay Başkanının önerileri dikkate alınarak Cumhurbaşkanınca düzenlenir. 2945 sayılı Kanun'un 6. maddesinin 2. fikrasına göre, “Kurul üyesi bakanlar ile diğer bakanların gündeme girmesini istedikleri konular, Başbakanın da görüşünü alarak Millî Güvenlik Kurulu Genel Sekreteri vasitasıyla Cumhurbaşkanına iletilir." Burada üzerinde pek durulmayan bir konuya dikkat çekmek isteriz. MGK gündeminin oluşturulmasında Genelkurmay Başkanının sivil otoriteden bağımsız bir şekilde Cumhurbaşkanına öneride bulunma yetkisine sahip kılınması, TSK'nin özerk konumunu bir başka açıdan ortaya koymaktadır. MGK gündeminin oluşturulması sürecine etki edebilme gücü bakımından Başbakan ve Genelkurmay Başkanının eşit bir konumda olması yerinde değildir. Demokratik sistemlerin askerî mercilerin sivil iktidara bağlı olması ilkesi çerçevesinde millî güvenlik konusundaki öncelikler hakkında Genelkurmay Başkanının Başbakandan farklı düşünmesi mümkün olmasa gerekir. $\mathrm{Bu}$ bakımdan Genelkurmay Başkanının gündemin oluşturulması için Başbakandan bağımsız bir şekilde Cumhurbaşkanına öneride bulunma yetkisine sahip kılınması uygun değildir. Bunun abartılı bir yorum olduğu düşünülmemelidir. Çünkü, Türkiye'de MGK gündemine giren konuların, yeri geldiğinde, siyaset dünyasının işleyişinde önemli etkilere sahip olduğu bir gerçektir. MGK gündeminin belirlenmesi önemli bir konudur. $\mathrm{Bu}$ konunun önemi bizzat Anayasa'da düzenlenmiş olmasından da çıkmaktadır. Gündemi öneriler doğrultusunda Cumhurbaşkanının belirlemesi Devlet başkanı olma sıfatı nedeniyle olağan karşılanabilir. Bununla birlikte, gündemin millî güvenliğin sağlanmasından sorumlu olan hükûmetin

54 Aynı yönde bkz. Erdoğan (2002), s. 255. ÖZAY'ın belirttiği gibi, millî güvenlik kavramı sadece dış güvenliği değil iç güvenliği de kapsadığından İçişleri Bakanı ve Jandarma Genel Komutanı MGK üyesidir. Özay (2004), s. 201. 
Başbakanı tarafindan belirlenmesi daha uygun olurdu. MGK gündeminin oluşturulması yetkisi Cumhurbaşkanında bulunmaya devam etse de gündeminin oluşturulması konusunda öneride bulunma yetkisi sadece Başbakana verilmelidir. Parlamenter sistemin özelliği gereği, bu tür bir düzenleme içinde Cumhurbaşkanının Başbakanın önerisini tartışmaması gerekir. Yine bu tür bir düzenleme içinde, Başbakan önerileri ve önceliklerini belirlerken gerek gördüğünde Genelkurmay Başkanının veya ilgili diğer kişilerin görüşlerini alabilir.

2945 say1l Kanun'un 5. maddesinin 30.07.2003 tarih ve 4963 say1l Kanun'un 25. maddesiyle değişik 1. fikrasına göre MGK iki ayda bir toplanır. Ancak, MGK Başbakanın teklifi üzerine veya doğrudan Cumhurbaşkanının çağrısı ile de toplanabilir. 2945 sayılı Kanun'un 5. maddesi değiştirilmeden önce MGK ayda bir toplanmaktaydı. Yapılan değişiklikle toplantı sayısı yıl bazında 12 'den 6'ya düşürülmüştür. $\mathrm{Bu}$ değişikliğin amaçlarından birinin, MGK'nın siyasal yaşamdaki ağırlığına yönelik eleştirileri bertaraf etmek olduğu açıktır.

2945 sayılı Kanun'un 7. maddesine göre, MGK kararları çoğunlukla alınır. Eşitlik halinde MGK Başkanının bulunduğu taraf çoğunluğu sağlamış sayılır. Yine aynı Kanun'un 10. maddesine göre, MGK görüşme tutanakları ve görüssmeleri açıklanamaz ve yayımlanamaz. Kararlar MGK'nın vereceği karara göre açıklanabilir ve yayımlanabilir.

\section{d) Millî Güvenlik Kurulu Genel Sekreterliği}

Millî Güvenlik Kurulu Genel Sekreterliği teșkilâtı, MGK'nın işleyişinde son derece önemli bir işleve sahiptir. 4963 sayılı Kanun'un getirdiği değişikliklerden önce MGK Genel Sekreteri asker kişi olma sıfatıyla, görev ve yetkileri ile tartışmalı bir konumdaydı.

2945 say1l Kanun'un 11. maddesine göre MGK Genel Sekreteri Başbakana bağlıdır. 2945 sayılı Kanun'un 15. maddesi 4963 sayılı Kanun'un 27. maddesiyle değiştirilmeden önce, "Millî Güvenlik Kurulu Genel Sekreteri Orgeneral/Oramiral rütbesinde Silâhlı Kuvvetler Mensupları arasından Genelkurmay Başkanının inhası, Başbakanın teklifi üzerine Bakanlar Kurulu kararı ile atanır." hükmünü taşımaktaydı. Değişikliklerden önceki durumda MGK Genel Sekreterinin Genelkurmay Başkanının önerisiyle atanması, asker kişi olması, sahip olduğu yetkiler bir arada değerlendirildiğinde gerçekten eleştirilecek bir tablo ortaya çıkmaktaydı. Değişiklikten sonra MGK genel sekreterinin asker kişi olması şartı kaldırıldı ve atanma yöntemi değiştirildi. 2945 sayılı Kanun'un değişik 15. maddesine göre, "Millî Güvenlik Kurulu Genel Sekreteri, Başbakanin teklifi ve Cumhurbaşkanının onayı ile atanır. Söz konusu atamanın, Türk Silâhlı Kuvvetleri mensupları arasından yapılmasının öngörülmesi hâlinde Genelkurmay Başkanının olumlu görüşü alınır.” MGK Genel Sekreterinin 
asker kişi olma zorunluluğuna son verilmesi, Genelkurmay Başkanının inha yetkisinin kaldırılması, MGK hakkındaki eleştirileri hafifletmek bakımından olumlu gelişmelerdir. Ancak MGK Genel Sekreterinin asker kişi olması halinde Genelkurmay Başkanının “olumlu görüşü”nün alınması zorunluluğu dikkat çekicidir. 2945 sayılı Kanun'un 11. maddesine göre MGK Genel Sekreteri Başbakana bağlı ise, Başbakanın bu konudaki takdirinin bir değeri olmalıdır. Genelkurmay Başkanından olumlu görüş alınması zorunluluğu bu takdiri neredeyse ortadan kaldırmaktadır. MGK Genel Sekreterinin asker kişi olması durumunda, Genelkurmay Başkanının inha yetkisinin kaldırılmış olmasının, Genelkurmay Başkanından olumlu görüş alınması şartının getirilmiş olması nedeniyle herhangi bir anlamı kalmamıştır. Düzenlemenin "olumlu görüş" alınması şartıyla değil sadece "görüş" şartıyla düzenlenmesi daha yerinde olurdu. Gerçekten, Başbakanın yapacağ 1 bir idarî işlemde, kendine karşı sorumlu olduğu belirtilen ve kamu görevlisi sıfatını taşıyan Genelkurmay Başkanından "olumlu görüş" alması gerçekten tuhaf bir durumdur.

Aşağıda üzerinde durulacağı üzere, 2965 sayılı Kanun'un 13. maddesi MGK Genel Sekreterinin görevlerini uzun ve ayrıntılı bir şekilde düzenlemişti. 2965 sayılı Kanun'un 13. maddesinin 4963 sayılı Kanun'un 26. maddesiyle değiştirilmesinin ardından MGK Genel Sekreterinin görev ve yetkileri sekretarya hizmetlerini yürütmek, kendisine kanunlarla ve Kurul tarafindan verilen görevleri yerine getirmek şeklinde kısaca sayılmıştır. Yine değişiklikten önceki 14. madde "Millî Güvenlik Kurulu Genel Sekreterliği, 13 üncü maddede belirtilen görevlerin yerine getirilmesinde, takip ve kontrol edilmesinde, yönlendirilmesinde, koordine edilmesinde ve denetlenmesinde Cumhurbaşkanı, Başbakan ve Millî Güvenlik Kurulu adına yetkilidir." düzenlemesini içermekteydi. $\mathrm{Bu}$ hüküm 4963 sayılı Kanun'un 35. maddesiyle tamamen yürürlükten kaldırılmıştır. Özetle, MGK Genel Sekreterinin görev ve yetkileri ciddî bir şekilde sınırlandırılmış, tabir yerinde ise olağanlaştırılmıştır.

e) Millî Güvenlik Kurulunun İdarî Teşkilât İçindeki Yeri ve Kararlarının Hukuksal Niteliği

Anayasa'nın 117. maddesinde millî güvenliğin sağlanmasından Bakanlar Kurulu sorumlu tutulduğu için, MGK'nın Bakanlar Kuruluna bildireceği görüşlerin kesin ve bağlayıcı bir güce sahip olmadığı, dolayısıyla söz konusu önerilerin Bakanlar Kurulunca benimsendiği ölçüde hukuksal bir değere sahip olacağı konusunda öğretide fikir birliği vardır ${ }^{55}$. Bu nedenle, MGK idarî teşkilât içinde "merkezdeki yardımcı kuruluşlar" arasında

55 Gözler (2003), C. I, s. 257-259; Günday (2003), s. 399; Soysal (1997), s. 236; Akgüner (1983), s. 221; Erdoğan (2002), s. 254; Aybay (1979), s. 79. 
sayılmaktadır ${ }^{56}$. MGK'nın idarî teşkilât içindeki yerini, kurul kararlarının hukuksal niteliği konusundan ayrı düşünmek mümkün değildir. Bu nedenle MGK kararlarının hukuksal niteliğini burada tartışmak uygun olacaktır.

MGK kararlarının bağlayıcı olmayan, görüş niteliğindeki işlemlerden olduğu genel olarak kabul edilse de, bu konu geçmişten bugüne tartışılmaktadır. $\mathrm{Bu}$ tartışmaların daha çok siyasal gerçeklikle bağlantılı olarak yapıldığını belirtelim. Zira normatif olarak MGK kararlarının bağlayıcı olduğunu iddia etmek güçtür. Fakat, en azından Anayasa'nın 118. maddesinde 03.10.2001 tarih ve 4709 sayılı Kanun ile yapılan değişiklik ve 2945 sayılı Millî Güvenlik Kurulu ve Millî Güvenlik Kurulu Genel Sekreterliği Kanunu'nda 15.01.2003 tarih ve 4789 sayılı Kanun ile yapılan değişikliklere kadar, MGK kararlarının görüş niteliğinde, bağlayıcı olmayan işlemler olduğunun tespiti konusunda şüphe doğuracak düzenlemeler mevcuttu. $\mathrm{O}$ halde öncelikle geçmişteki tartışmalar üzerinde kısaca durup yapılan değişikliklerin ne getirdiğini açıklamaya çalışalım.

Anayasa'nın 118. maddesi 03.10.2001 tarih ve 4709 sayılı Kanun ile değiştirilmeden önce, MGK'nın yine görüş niteliğinde olan kararlarından Devletin bağımsızlığı, ülkenin bütünlüğü ve bölünmezliği, toplumun huzur ve güvenliğinin korunması hususunda alınmasını zorunlu gördüğü tedbirlere ait kararlar Bakanlar Kurulunca "öncelikle dikkate alınır" düzenlemesini içermekteydi. Öğretide, bu düzenlemedeki "öncelikle dikkate alınır" ifadesi hakkında, MGK'nın sayılan konulardaki kararlarının bağlayıcı olduğu izlenimini uyandırdığ $1^{57}$, tam bir bağlayıcılık ifade etmese de kararların görüş bildirme niteliğgini zedelediği yorumları yapılmıştı ${ }^{58}$. Bununla birlikte, "öncelikle dikkate alma" ifadesinin Bakanlar Kurulunun konuyu mutlaka görüşecek olması anlamına geldiği; ancak, nihai kararı verme yetkisinin yine Bakanlar Kurulunda bulunduğu da ifade edilmekteydi ${ }^{59}$.

2945 sayılı Kanun'da da MGK kararlarının sadece bir görüş olduğu yolundaki kabule şüphe ile yaklaşılmasına yol açabilecek düzenlemeler vard1. 2945 sayılı Kanun'un "Kararların dağıtım ve takibi" başlıklı 9. maddesine göre, MGK Genel Sekreteri MGK kararlarının uygulanıp uygulanmadığını takip etme yetkisine sahipti. Yine 2945 sayılı Kanun'un 13. maddesinde aynı doğrultuda düzenlemeler yer almaktaydı. Bağlayıcı

56 Bkz. Gözler (2003), C. I, s. 232 vd.; Günday (2003), s. 396-400; Gözübüyük/Tan (2004), s. 214-217; Yıldırım (1999), s. 87-92.

57 Günday (2003), s. 397.

58 Soysal (1997), s. 236.

59 Erdoğan (2002), s. 255. ERDOĞAN, Bakanlar Kurulunun olağanüstü hal ve sıkıyönetim ilan etmeden önce MGK'dan görüş almasının zorunlu hale getirilmiş olmasının MGK kararlarını güçlendiren bir başka unsur olduğunu ifade etmektedir. Erdoğan (2002), s. 255. 
olmadığ1 söylenen ya da düşünülen kararların akıbetinin MGK Genel Sekreteri tarafından takip edilmesinin anlamını kavramak güçtü.

Yapılan tartışmalar ve yöneltilen eleştiriler neticesinde MGK kararlarının görüş niteliğinde kararlar olduğu konusundaki şüpheleri dağıtmak ya da bu niteliği sağlamlaştırmak amacıyla gerek Anayasa'da gerekse 2945 sayılı Kanun'da çeşitli değişikler yapılmıştır.

İlk önce 03.10.2001 tarih ve 4709 say1lı Kanun'un 32. maddesiyle Anayasa'nın 118. maddesinin 3. fikrasındaki "Millî Güvenlik Kurulu; Devletin millî güvenlik siyasetinin tayini, tespiti ve uygulaması ile ilgili kararların alınması ve gerekli koordinasyonun sağlanması konusundaki görüşlerini Bakanlar Kuruluna bildirir. Kurulun, Devletin varlığı ve bağımsızlığl, ülkenin bütünlüğ̈̈ ve bölünmezliği, toplumun huzur ve güvenliğinin korunması hususunda alınmasını zorunlu gördüğ̈̈ tedbirlere ait kararlar Bakanlar Kurulunca öncelikle dikkate alınır." düzenlemesi, "Millı̂ Güvenlik Kurulu; Devletin millî güvenlik siyasetinin tayini, tespiti ve uygulanmast ile ilgili alınan tavsiye kararlart ve gerekli koordinasyonunun sağlanması konusundaki görüşlerini Bakanlar Kuruluna bildirir. Kurulun, Devletin varlı̆̆l ve bağgmsızlı̆̆ı, ülkenin bütünlüğ̈̈ ve bölünmezliği, toplumun huzur ve güvenliğinin korunması hususunda alınmasını zorunlu gördüğ̈̈ tedbirlere ait kararlar Bakanlar Kurulunca değerlendirilir." şeklinde değiştirilmiştir. Daha önceki düzenlemede sadece "görüş" sözcüğü yer alırken, düzenlemeye bir de "tavsiye" sözcüğü eklenmiştir. Yeni düzenlemede MGK "millî güvenlik siyasetinin tayini, tespiti ve uygulanması ile ilgili tavsiye"de bulunmakta, "gerekli koordinasyonun sağlanması konusunda görüş" bildirmektedir. Bu durumda MGK kararları tavsiye ve görüş olarak iki türlüdür. Yeni düzenlemeyle MGK kararlarının niteliği konusundaki şüphe ve tartışmaların dinmesi bir tarafa sorun daha da karmaşık bir vaziyet almıştır. Gerek "tavsiye" gerekse "görüş" niteliğindeki işlemlerin icraî işlemler olmadığını genel olarak söyleyebiliriz. Bununla birlikte, 1961 Anayasası'nın 111. maddenin 1971 yılında değiştirilmesiyle düzenlemeye "tavsiye" sözcüğünün eklendiğini, bunun MGK kararlarına daha fazla ağırlık verilmesi yönünde adım teşkil ettiğini ${ }^{60}$ ve "görüş bildirme"nin alışılmış ve yerleşmiş anlamına göre bağlayıcı gücü olmayan "istişare" ya da "danışma"da bulunmaktan ibaret ve genellikle yetkili organ ve makamın isteği üzerine verildiğini; "tavsiye" kararının ise, en azından eşitlerin birbirine verdiği direktif anlamını içerdiğini ve muhatap olanın takdirini az çok kısıtladığını belirtmiştik ${ }^{61}$. Anayasa'nın 118. maddesinin 3. fikrasına eklenen "tavsiye" sözcüğü hakkında da aynı yorum geçerlidir. Dolayısıyla bu değişiklikle MGK kararlarının bağlayıcılık gücünün daha da

\footnotetext{
60 Soysal (1997), s. 235.

61 Duran (1982), s. 130; Akgüner (1983), s. 220.
} 
arttığı iddia edilebilirr ${ }^{62}$. Bu değişikliğin amacı MGK kararlarının bağlayıcı olmadığına yönelik anlamı güçlendirmekse, bu amaç kesinlikle hâsıl olmamıștır.

Diğer bir değişiklik "Bakanlar Kurulunca öncelikle dikkate alınır" ifadesi yerine "Bakanlar Kurulunca değerlendirilir" ifadesinin getirilmiş olmasıdır. Bu değişikliğin MGK kararlarının hukuksal niteliği konusunda çok ciddî bir yenilik getirdiğini söylemek mümkün değildir. Gerçekten de, daha önce naklettiğimiz belli bazı şüphelere rağmen, değişiklikten önceki "Bakanlar Kurulunca öncelikle dikkate alınır" ifadesinden MGK kararlarının icraî işlemler olduğu sonucu çıkarılamazd1 ${ }^{63}$. Değişikliğin anlamlı bir sonucu, MGK'nın devletin varlığı ve bağımsızlığı, ülkenin bütünlüğü ve bölünmezliği, toplumun huzur ve güvenliğinin korunması hususunda alınmasını zorunlu gördüğü tedbirlere ait kararların Bakanlar Kurulunca değerlendirileceğinin düzenlenmesinin, bunun dışındaki kararların Bakanlar Kurulunca değerlendirilmek zorunda olmadığı anlamına gelmesidir. Aksi halde bu düzenlemeyi anlamlandırmak mümkün değildir. Bununla birlikte 2945 sayılı Kanun'un 8. maddesine göre, "Millî Güvenlik Kurulu kararları, Başbakan tarafindan Bakanlar Kurulu gündemine öncelikle alınmak suretiyle görüşülür ve gerekli kararlar alınır." $\mathrm{Bu}$ düzenlemede MGK kararlarının konusu ile ilgili olarak herhangi bir ayrım yapılmaksızın Bakanlar Kurulu gündemine alınacağı hükme bağlanmıştır. 2945 sayılı Kanun'un 8. maddesinin Anayasa ile uyum içinde olması için "Millî Güvenlik Kurulunun Devletin varliğg ve bă̆ımsızliğl, ülkenin bütünlüğ̈̈ ve bölünmezliği, toplumun huzur ve güvenliğinin korunmast hususunda alınmasını zorunlu gördüğü tedbirlere ait kararlar Başbakan tarafindan Bakanlar Kurulu gündemine öncelikle alınmak suretiyle görüşülür ve gerekli kararlar alınır." şeklinde yeniden kaleme alınması gerekir. Bu arada, Bakanlar Kurulunun MGK kararlarını değerlendirme zorunluluğunun bunları icraî işlemlerle benimseme zorunluluğu anlamına gelmediği açıktır.

Anayasa'daki değişiklikler kadar önemli olan bazı değişiklikler 2945 sayılı Millî Güvenlik Kurulu ve Millî Güvenlik Kurulu Genel Sekreterliği Kanunu'nda gerçekleştirilmiştir. Gerçekten de MGK kararlarının niteliği konusundaki tartş̧malar geçmişte hep Anayasa'daki düzenlemelerle sınırlı kalmıştı. Oysa 2945 sayılı Kanun'da, özellikle MGK kararlarıyla ilgili olarak MGK Genel Sekreterinin sahip olduğu yetkiler son derece ilginçti. Öncelikle 2945 sayılı Kanun'un 9. maddesi MGK kararlarına ilişkin uygulamaların MGK Genel Sekreteri tarafindan takip edileceğini, MGK Genel Sekreterinin Bakanlar Kurulu kararı haline getirilmeyenler hakkında Cumhurbaşkanına, Başbakana ve MGK'ya bilgi sunacağını düzenlemişti. MGK Genel

62 Gözler (2003), C. I, s. 258.

63 Gözler (2003), C. I, s. 257. 
Sekreterinin MGK kararlarını takip görevi "Genel Sekreterin görevleri" başlığını taşıyan 9 bentten oluşan, oldukça yarıntılı düzenlemeler içeren 13. maddesiyle pekiştirilmişti. Görüş niteliğindeki kararlar hakkında bu tür düzenlemelerin getirilmiş olmasını anlamak mümkün değildi. Neyse ki 2945 sayılı Kanun'un 9. maddesi 30.07.2003 tarih ve 4963 sayılı Kanun'un 35. maddesiyle tamamen yürürlükten kaldırılmıştır. Bunun yerine yine 4963 sayılı Kanun'un 24. maddesiyle 2945 sayılı Kanun'un 4. maddesi değiştirilerek, “...Baş̧bakan, Millî Güvenlik Kurulunun tavsiye kararlarının ve görüşlerinin değerlendirilmek üzere Bakanlar Kuruluna sunulması ve Bakanlar Kurulunda kabulü halinde bu tavsiye kararlarının uygulanmasinin koordinasyonu ve izlenmesi için bir Başbakan yardımcısını görevlendirebilir." düzenlemesi getirilmiştir. Yeni düzenleme tavsiye kararlarının Bakanlar Kurulunca kabulü halinde uygulanmasının koordinasyonu ve izlenmesini öngörerek daha önceki düzenlemelerin doğurduğu şüpheleri bertaraf etmiştir. Çünkü daha önceki düzenlemeler, MGK kararlarının Bakanlar Kurulunca kabul edilsin ya da edilmesin akıbetinin sonuçlarının MGK Genel Sekreteri tarafından takip edileceğini düzenlemekteydi. 2945 sayılı Kanun'un 9. maddesi değişiklikten önce, “...Bu kararlara iliş̧kin uygulamalar Millî Güvenlik Kurulu Genel Sekreterliği tarafindan takip edilerek sonuçları hakkında Başbakana, Cumhurbaşkanına ve Millî Güvenlik Kuruluna belli süreler içinde bilgi verilir." düzenlemesini taşımaktaydı. Bu düzenlemedeki "kararlara ilişkin uygulamalar" ifadesi, kararların Bakanlar Kurulu tarafindan icraî işlemlerle hayata geçirilmemiş olması hallerini de içerir şekilde yorumlanmaya müsaitti. Özetle, 2945 sayılı Kanun MGK kararlarının Bakanlar Kurulunca icraî işlemlerle hayata geçirilenlerinin koordinasyonu ve takibini öngörmek ve bu işi de Başbakan yardımcısına vermekle son derece olumlu bir düzenleme getirmiştir.

4963 say1l Kanun'un 26. maddesi ile, 2945 say11 Kanun'un 13. maddesi "Millî Güvenlik Kurulu Genel Sekreterliği; a) Millî Güvenlik Kurulunun sekreterlik hizmetlerini yürütür, b) Millî Güvenlik Kurulunca ve kanunlarla verilen görevleri yerine getirir." şeklinde değiştirilmiştir.

Yukarıda naklettiğimiz 2945 sayı1ı Kanun'da yapılan köklü değişiklikler MGK kararlarının tavsiye ve görüş niteliğini daha da güçlendirmiş ve bu konudaki şüpheleri bir ölçüde bertaraf etmiştir.

Normatif değerlendirmelerin yanında siyasal gerçeklikle iç içe olan uygulamaların nasıl gerçekleştiği başka bir sorundur. Örneğin, TANÖR, "MGK kararları 1961'den beri güya tavsiye niteliğindedir. Bu 35 yılda tavsiyelerin aksine bir karar çıktığını hatırlamıyorum. Böyle tavsiye kararı olmaz." diyerek MGK kararlarının niteliği konusundaki görüşünü siyasal 
gerçeklikten yola çıkarak açıklamaktadır ${ }^{64}$. Yine MGK kararlarının niteliği konusunda bir Genelkurmay Eski Başkanının görüşü dikkat çekicidir. Genelkurmay Eski Başkanlarından Doğan GÜREŞ'e göre, "Anayasamızda tanımlandığ 1 gibi MGK, millî güvenlik siyasetini tayin eder ki, bu bütün politikaların tanrısıdır, anayasasıdır. Buna aykırı davranılması düşünülemez. Bu nedenle 1982 Anayasası, 'MGK hükûmete tavsiye eder' ifadesi yerine, 'bildirir' ifadesini kullanmıştır. Anayasal durum bu olduğuna göre MGK kararlarının tavsiye mahiyetinde değerlendirilmesi yanlıştır."

Sonuç olarak belirtmek gerekir ki, MGK hakkında yapılmış olan ve yapılan tartışmaların siyasal boyutu normatif değerlendirmelerden çok daha geniştir. Tartışmalar daha çok TSK'nın Türk siyasal tarihi ve sistemi içindeki rolünden ve MGK'nın bir kanadının asker üyelerden oluşmasından kaynaklanmaktadır.

D) TÜRK SİLÂHLI KUVVETLERİ ÍLE İLGILİ YAN KURULUŞLAR

\section{Savunma Sanayii Kuruluşları}

11.07. 1985 tarihli ve 3238 say11 Kanun ${ }^{66}$ ile modern savunma sanayiinin geliştirilmesi ve TSK'nın modernizasyonunun sağlanması amacıyla (md. 1) çeşitli düzenlemeler yapılmıştır. Bu Kanun ile Savunma Sanayii Yüksek Koordinasyon Kurulu, Savunma Sanayii İcra Komitesi, Savunma Sanayii Destekleme Fonu ve Savunma Sanayii Müsteşarlığı (SSM) kurulmuştur.

\section{a) Savunma Sanayii Yüksek Koordinasyon Kurulu}

Savunma Sanayii Yüksek Koordinasyon Kurulu, Başbakanın başkanlığında Genelkurmay Başkanı, ekonomiden sorumlu Devlet Bakanı, Millî Savunma Bakanı, Dışişleri Bakanı, Maliye ve Gümrük Bakanı, Sanayi ve Ticaret Bakan1, Kuvvet Komutanları, Jandarma Genel Komutan1, Başbakanlık Müsteşarı, Devlet Planlama Teşkilâtı Müsteşarı ile Hazine ve

64 Tanör, B.: (Şahin ALPAY 'in röportaj1), Milliyet Gazetesi, 30.12.1996. SOYSAL Başbakan ve sayılan bakanların MGK üyesi olmasının "tavsiye niteliğindeki kararların Bakanlar Kurulunca benimsenmesini kolaylaştırdığını ifade ediyor. Soysal (1997), s. 235; ERDOĞAN bu konuda gözden kaçmayacak bir çelişkiye şu şekilde dikkat çekiyor: "...MGK ile Bakanlar Kurulu adeta iç içe geçmiş durumdadır. Çünkü, Başbakan ve üç bakan aynı zamanda Kurulun da üyesidir. Buna, Kurulun başkanı Cumhurbaşkanını da eklemek gerekir. $\mathrm{Bu}$ durumda, bir bakıma, Hükümet kendi kendine görüş bildirmektedir." Erdoğan (2002), s. 255-256.

65 Milliyet Gazetesi, 04.03.1997.

66 Savunma Sanayii Müsteşarlığının Kurulması ve 11 Temmuz 1939 Tarih ve 3670 Sayılı Millî Piyango Teşkiline Dair Kanun'un İki Maddesi ile 23 Ekim 1984 Tarih ve 3065 Sayılı Katma Değer Vergisi Kanununun Bir Maddesinde Değişiklik Yapılması Hakkında Kanun. 
Dış Ticaret Müsteşarlığından meydana gelir. Kurul, Başbakanın daveti üzerine yılda iki kez toplanır (3238 sayılı Kanun md. 3).

Savunma Sanayii Yüksek Koordinasyon Kurulu, Bakanlar Kurulu tarafindan onaylanan genel strateji doğrultusunda, planlama ve koordinasyonun sağlanmasını takip etmek, düzenleyici direktifler vermek, Genelkurmay Başkanınca hazırlanan Stratejik Hedef Planına uygun olarak Savunma Sanayii Fonu ${ }^{67}$ ile tedariki öngörülen silâhlı sistemler ile araç ve gereçlerin tedarik şeklini tespit etmekle görevlidir (3238 sayılı Kanun md. $4)$.

\section{b) Savunma Sanayii İcra Komitesi}

Savunma Sanayii İcra Komitesi Başbakanın başkanlığında, Millî Savunma Bakanı ve Genelkurmay Başkanından oluşur. Komite Başbakanın daveti üzerine toplanır (3238 sayılı Kanun md. 5).

Komitenin görevleri Yüksek Koordinasyon Kurulu kararları doğrultusunda ve TSK'nın ihtiyacı olan silâh, araç ve gereçlerin üretimi ile yurt içinden veya yurt dışından temini konusunda kararlar almaktır (3238 sayılı Kanun md. 6). Savunma Sanayii İcra Komitesinin en önemli görevi TSK'nın ihtiyaç duyduğu malzemelerin tedariki konusunda nihai kararları vermeye yetkili olmasıdır. İcra Komitesi söz konusu görevini yerine getirirken Savunma Sanayii Müsteşarlığına talimatlar verebilir (3238 sayılı Kanun md. 6/d).

\section{c) Savunma Sanayii Müsteşarlığı (SSM)}

Savunma Sanayii Müsteşarlığı, Millî Savunma Bakanlığına bağlı, tüzel kişiliğe sahip bir kuruluştur (3238 sayılı Kanun md. 7).

Savunma Sanayii Müsteşarlı̆̆g, Savunma Sanayii İcra Komitesinin aldığı kararları uygular; ihtiyaç duyulan modern silâh, araç ve gereçlerin özel veya kamu kuruluşlarında üretimini planlar; modern silâh, araç ve gereçleri araştırır, prototiplerinin üretimini sağlar, avans verir, uzun vadeli siparişleri ve diğer malî ve ekonomik teşvikleri tespit eder; savunma sanayii fonundan kredi verir veya yurt içinden ve yurt dışından kredi alır; gerektiğinde yerli ve yabancı sermayeli şirketler kurar ve bunlara iştirak eder (3238 sayılı Kanun md. 10) ${ }^{68}$.

3238 sayılı Kanun'un 12. maddesine göre, “Bu Kanunun amacının gerçekleştirilebilmesi için T.C. Merkez Bankası nezdinde Müsteşarlık emrinde Savunma Sanayii Destekleme Fonu kurulmuştur."

68 Anayasa Mahkemesi, savunma sanayiinin geliştirilmesi konusunda özel sektör ve yabancı sermayeli kuruluşlarla işbirliğine gidilmesinin Anayasa'nın 5. maddesine aykırı olduğu yönündeki iddiaları reddetmiştir. A.M., E. 1986/1, K. 1987/10, K.T. 05.05.1987, A.M.K.D., S. 23, s. 196-197. 
Savunma sanayiine ilişkin yapılacak harcamalarda 1050 sayılı Muhasebe-i Umumiye Kanunu, 2886 sayılı Devlet İhale Kanunu ve 832 sayılı Sayıştay Kanunu uygulanmaz (3238 sayılı Kanun md. 11).

\section{(OYAK)}

2. Ayrı Bir Sosyal Güvenlik Sistemi: Ordu Yardımlaşma Kurumu

Ordu Yardımlaşma Kurumu (OYAK) 27 Mayıs darbesinin hemen ardından, darbenin ikincil sebeplerinden biri olan, subayların ve astsubayların ekonomik durumunu iyileştirmek için kurulmuştu. Esasen, 27 Mayıs darbesinden sonra kurulan tek yardımlaşma kurumu OYAK değildi. Memurlar için MEYAK, işçiler için IYAK, öğretmenler için ÖYAK kurulmuştu. Ancak OYAK dışındaki bütün yardımlaşma kurumları bir süre sonra battı. OYAK ise olağanüstü bir gelişme gösterdi ${ }^{69}$.

OYAK, 03.01.1961 tarihli ve 205 sayılı Ordu Yardımlaşma Kurumu Kanunu ile Millî Savunma Bakanlığına bağlı olarak kurulmuştur. OYAK özel hukuk hükümlerine göre faaliyette bulunur, tüzel kişiliğe sahiptir, malî ve idarî bakımdan özerktir (205 sayılı Kanun md. 1/1, 2).

OYAK bir tüzel kişi olarak nitelendirilse de bunun bir kamu tüzel kişiliği mi yoksa özel hukuk tüzel kişiliği mi olduğu açık değildir. Aşă̆ıda değinileceği gibi OYAK'a 205 sayılı Kanun çerçevesinde, özel hukuk tüzel kişilerinin sahip olması düşünülemeyen çeşitli kamusal yetki ve imtiyazlar tanınmıştır. Dolayısıyla OYAK'ın bir kamu tüzel kişisi olduğu kabul edilmelidir $^{70}$.

Muvazzaf subay, sözleşmeli subay ve astsubayların maaşından alınan $\% 10$ oranındaki kesenekler, yedek subayların maaşlarından kesilen \%5 oranındaki kesenekler ve Millî Savunma Bakanlığı, Jandarma Genel Komutanlığ1 ve OYAK'ın \%50 sermayesine sahip olduğu şirket çalışanlarının ve Kuruma daimi üye olmayı kabul eden bilumum maaşlı ve ücretli sivil memur ve müstahdemlerin maaşlarından alınan $\% 10$ kesenekler (205 sayılı Kanun md. 18) OYAK'ın gelirleri arasında önemli bir yer tutar.

OYAK üyelerine veya üyelerin mirasçılarına emeklilik yardımı, emekli maaşı, malûliyet yardımı, ölüm yardımı gibi olanaklar sunar (205 sayılı Kanun md. md. 20 vd.).

OYAK'a çeşitli ayrıcalıklar tanınmıştır. OYAK kurumlar vergisine tâbi değildir, OYAK'a yapılacak bağışlar, OYAK'ın üyelerine her ne ad altında olursa olsun yapacağ 1 yardımlar veraset ve intikal vergisinden ve gelir vergisinden muaftır. OYAK yapacağı her türlü işlemde damga

Tanilli, S.: Nas1l Bir Demokrasi İstiyoruz ?, İstanbul 1994, s. 158.

70 Yılmaz, E.: "Ordu Yardımlaşma Kurumunun Hukuksal Niteliği", A.İ.D., C. 22, S. 1, 1989, s. 73. 
resminden muaftır. OYAK'ın her türlü gelirleri gelir vergisinden muaftır (205 sayılı Kanun md. 35).

Kurumun her çeşit malları ile gelir ve alacakları, devlet malları hak ve rüçhanlığını haizdir. Bunlara karşı suç işleyenler, devlet mallarına karşı suç işleyenler gibi takibata tâbi tutulurlar (205 sayılı Kanun md. 37). Bütün bu ayrıcalıkların OYAK'ın büyümesinde etken olduğu açıktır.

OYAK'ın mensupları açısından tek sosyal güvenlik kurumu olmadığını da belirtmek gerekir. OYAK ek bir sosyal güvenlik kuruluşudur.

OYAK'ın yatırımlarının büyüklüğü şaşırtıcıdır ${ }^{71}$. TSK'nın OYAK aracılığı ile ekonomik sisteme eklemlendiği, bu ilişki biçimi nedeniyle artık tarafsız ve politika dışında kalamayacağı; OYAK'ın kapitalist düzen içindeki yerini, dev bir finans ve sanayi gücüne dönüşmesini, çok uluslu şirketlerle bağlarını "sosyal güvenlik" ereğiyle açıklamanın güç olduğu ileri sürülmüştür ${ }^{72}$.

\section{MILLî SAVUNMA HIZMETININ YÜRÜTÜLMESINDE IDAREYE DÜŞEN GÖREVLER}

\section{A) ANAYASA'YA GÖRE TÜRK SILÂHHLI KUVVETLERINIIN GÖREVLERI}

Anayasa'nın Başkomutanlık ve Genelkurmay Başkanlığını düzenleyen 117. maddesi, silâhlı kuvvetlerin "yurt savunmasına" hazırlanmasından Bakanlar Kurulunun sorumlu olduğunu düzenlemektedir. Burada "yurt savunmasından" söz edildiğine göre pozitif anayasa hukukumuz bakımından TSK'nın işlevi ya da görevi "millî savunma" dır" Millî savunma bir kamu hizmetidir ${ }^{74}$.

Millî savunma, ileride ayrıntıları ile göreceğimiz gibi millî güvenlik genel kavramının kapsamına giren bir alt kavramdır. Millî savunma faaliyeti genel olarak ülkenin dışarıdan gelen saldırılara karşı korunması ve muhtemel saldırılar için hazırlıklı bulunulması anlamına gelmektedir. Gerek millî güvenliği sağlamak gerekse millî savunma faaliyetini yürütmek Bakanlar Kurulunun sorumluluğundadır. Genelkurmay Başkanı ve kuvvet komutanlarının Millî Güvenlik Kurulunda yer alması, TSK'nın işlevinin doğrudan millî güvenliğe yönelik olmasından değil, millî savunmanın, millî güvenliğin bir unsuru olmasından kaynaklanmaktadır ya da bunu böyle kabul etmek gerekir.

\footnotetext{
71 OYAK'ın yatırım ve hisselerinin listesi için bkz. Parlar, S.: Silâhlı Bürokrasinin Ekonomi Politiği, İstanbul 1997, s. 88-100.

72 Ahmad, F.: Demokrasi Sürecinde Türkiye, Çev.: Fethi, A., İstanbul 1996, s. 273-274; Parlar (1997), s. 103.

73 Erdoğan (2002), s. 238.

74 Balta, T. B.: İdare Hukukuna Giriş, Ankara 1968/1970, s. 16; Kıratı (1973), s. 91.
} 
Millî savunma hizmetine ve TSK'nın kullanılmasına ilişkin önemli yetkiler TBMM'ye aittir. Anayasa'nın 92. maddesine göre "Milletlerarası hukukun meşrûu saydı̆̆ hallerde savaş ilanına...", "...Türk Silâhlı Kuvvetlerinin yabancı ülkelere gönderilmesine veya yabancı silâhlı kuvvetlerin Türkiye'de bulunmasina izin verme yetkisi Türkiye Büyük Millet Meclisine aittir." Yine Anayasa'nın 92. maddesine göre ani saldırılarda TSK'nın kullanılmasına Cumhurbaşkanı da karar verebilir.

\section{B) İÇ HİZMET KANUNU'NA GÖRE TÜRK SİLÂHLI KUVVETLERININ GÖREVLERİ}

27 Mayıs darbesinin ardından Millî Birlik Komitesi tarafından çıkarılan 04.01.1961 tarihli ve 211 sayılı İç Hizmet Kanunu silâhlı kuvvetlerin görevini askerlik mesleğinin gereklerine uygun olarak yerine getirmesine ilişkin hükümleri içerir. Bu Kanun'un oluşturduğu sisteme "askerî idare hukuku" adı verilebilir ${ }^{75}$.

211 sayılı Kanun'un “Umumi Vazifeler” başlığını taşıyan 35. maddesi "Silâhl Kuvvetlerin vazifesi; Türk yurdunu ve Anayasa ile tayin edilmiş olan Türkiye Cumhuriyetini kollamak ve korumaktır." hükmünü, 36. maddesi ise "Silâhlı Kuvvetler, harp sanatını ögrenmek ve ögretmekle vazifelidir. Bu vazifenin ifası için lâzım gelen tesisler ve teşkiller ve tedbirler alınır." hükmünü getirmiş̧tir. Buna paralel bir hüküm Kanun'un 2. maddesinde "askerlik" tanımında yer almaktadır. Buna göre, "Askerlik: Türk vatanını, istiklal ve Cumhuriyetini korumak için harp sanatını öğrenmek ve yapmak mükellefiyetidir..." 211 say1l Kanun'un 2., 35. ve 36. maddeleri TSK'nın görevlerini düzenlemektedir.

211 sayılı Kanun'un 35. maddesindeki "Cumhuriyeti korumak ve kollamak" görevi önem taşımaktadır. 27 Mayıs darbesi 2771 sayılı İç Hizmet Kanunu'nun 34. maddesindeki, 12 Eylül darbesi de bugün yürürlükte olan 211 sayıl1 Kanun'un 35. maddesindeki aynı ifadelere dayanılarak yapılmışt ${ }^{76}$. Buradaki "Cumhuriyeti korumak ve kollamak" ifadesini millî savunma hizmeti ölçüsünde, Cumhuriyete "dışarıdan gelebilecek" tehlikelere karş1 korumak ve kollamak olarak anlamak gerekir. Cumhuriyete yönelecek iç tehlikeleri önleme yetkisi öncelikle kolluk güçlerine, bastırma yetkisi de yargı mercilerine aittir. Sıkıyönetim halinde ise iç tehlikeleri önleme yetkisi, siyasî iradenin sorumluluğu altında TSK'nındır. Ancak bu yorum, Kanun

\footnotetext{
Erdoğan (2002), s. 241.

76 Öztürk, M.: Ordu ve Politika, Ankara 1993, s. 70, 86. Özellikle darbeler açısından bakıldığında İç Hizmet Kanununun bu maddesine dayanılmasının hukuksal bakımdan hiç bir değerinin bulunmadığı tartışmadan uzaktır. Hiçbir kanun gerektiğinde bir anayasanın uygulanmasının durdurulması ve yürürlükten kaldırılması yetkisini herhangi bir makama veremez. Söz konusu hüküm TSK'yı rahatsız eden gelişmeler olduğunda politikaya ve siyasal iktidara uyarıda bulunmayı meşrulaştırmak için kullanılabilmektedir.
} 
biraz daha dikkatli okunduğunda tartışmalı hale gelebilir. Çünkü Kanun'un 35. maddesi, "Anayasada tayin edilen" Cumhuriyeti korumak ve kollamaktan söz etmektedir. Anayasa'da tayin edilen Cumhuriyet demek, bir bakıma, "Anayasa'da ifadesini bulan nitelikleri itibariyle Cumhuriyet" demektir. Dolayısıyla, Kanun'un hükmünden TSK'nın görevinin sadece Cumhuriyeti yani ülkeyi korumak değil, Cumhuriyetin Anayasa'daki niteliklerini de korumak olduğu çıkarılabilir. Esasen, Anayasa'da tayin edilen Cumhuriyetle, yani Cumhuriyetin nitelikleriyle, ülkenin dış bir saldırıya maruz kalması tehlikesi arasında doğrudan bir ilgi kurmak güçtür. Örneğin, ülke topraklarının işgalinin, Cumhuriyetin laiklik ilkesine veya Atatürk milliyetçiliğine yönelik olduğunu söylemek mümkün değildir. Burada tehlikede olan Cumhuriyetin Anayasa'da tayin edilen nitelikleri değil, bizzat maddî varlığı ve bağımsızlığıdır. Cumhuriyetin niteliklerine yönelik "tehditler" olsa olsa ülke içindeki siyasal oluşumlarla ilgili olabilir. Özetle, 211 sayılı Kanun'un 35. maddesinin TSK'ya "Cumhuriyetin Anayasa'da ifadesini bulan niteliklerini" korumak ve kollamak görevini verdiği söylenebilir. Nitekim, bir görüşe göre, "...Anayasa'da tayin edilmiş Türkiye Cumhuriyeti ise, Anayasa'da gösterilmiş nitelikleri ile ele alınmalıdır. Asker, Cumhuriyetin niteliklerini bilmekle; Cumhuriyeti koruma kapsamındaki somut görevlerini öğrenmiş olacaktır." ${ }^{77}$ Ayrıca İç Hizmet Yönetmeliği'nin ${ }^{78}$ 85/1. maddesinde de "Vazifesi Türk Yurdu ve Cumhuriyetini içe ve dışa karşı lüzumunda silâhla korumak olan, Silâhlı Kuvvetlerde..." ifadesi kullanılmıştır. Hiç şüphe yok ki, "Cumhuriyeti içe karşı gerektiğinde silâhla korumak" Cumhuriyetin niteliklerini korumakla ilgilidir. Öğretide de, anayasal düzenin işletilememesi, milletin temel hukuk fikrinin özündeki ülke ve millet bütünlüğü, Cumhuriyet ve Atatürk ilkelerinin mutlak ve ciddî tehlikeyle karşı karşıya bulunması hallerinde, silâhlı kuvvetlerin yönetime müdahale yetkisinin bulunduğu ileri sürülmektedir ${ }^{79}$.

TSK'nın ülkeyi dış saldırılara karşı savunma görevini nasıl yerine getireceği belli iken ${ }^{80}$ "içe karşı" nasıl koruyacağı hukuksal düzenlemelerde yer almamıştır. Belki, sıkıyönetim veya olağanüstü hal rejiminin TSK'ya böyle bir görev verdiği söylenebilir. Ancak, 211 sayılı Kanun ve İç Hizmet

77 Doğruer, S.: Askerler İçin Hukuk Rehberi, Kara Harp Okulu Komutanlığı Yayını, Ankara 1998, s. 3.

RG., 6.9.1961, S. 10899.

79 Yayla, Y.: Anayasa Hukuku (Ders Notlar1), İstanbul 1986, s. 32.

80 Bkz., 04.11.1983 tarihli ve 2941 sayılı Seferberlik ve Savaş Hali Kanunu; 07.08.1944 tarih ve 4654 sayılı Memleket İçi Düşmana Karşı Silâhlı Müdafaa Mükellefiyeti Kanunu. 4654 sayılı Kanun ülkenin işgali teşebbüsü halinde sivillerin silâhlı direnişini düzenlemektedir. 
Yönetmeliği TSK'nın Cumhuriyeti içe karşı korumak görevini olağanüstü dönemlere özgülememiştir.

Yukarıda tartıştığımız hükümler TSK'ya Cumhuriyetin ilkelerini korumak görevini verir niteliktedir. TSK da bu hükümlere dayanarak ülkedeki siyasal süreçlere ve oluşumlara müdahale etme yetkisini bulmaktadır. Demokratik bir devlette silâhlı kuvvetlerin görevi "ülkeyi dış tehditlere karşı savunma"yla sınırlanmalıdır.

211 sayılı Kanun'un 36. maddesi TSK'nın barış dönemlerindeki işlevine ilişkindir. Bu maddeye göre TSK'nın barış dönemindeki görevi yurt savunmasına hazırlanmaktır. Yine bu maddeye göre, silâhlı kuvvetlerin yurt savunmasına hazırlanmasından Bakanlar Kurulu sorumlu olduğu için, bu konuda herhangi bir idarî ihmal olması durumunda, Bakanlar Kurulu Genelkurmay Başkanı hakkında sorumluluğunun gerektirdiği işlemi yapabilir ${ }^{81}$.

Barış döneminde TSK'nın yurt savunmasına hazırlanmasında askerî eğitimin doğal olarak büyük önemi vardır. 211 sayılı Kanun, TSK'nın eğitim faaliyetini sadece askerî eğitimle sınırlamamıştır. Kanun'un 39. maddesine göre "Silâhl Kuvvetlerde askerî eğitim ile beraber ahlak ve maneviyatın yükselmesine ve milli duyguların kuvvetlendirilmesine bilhassa itina olunur."

Askerî eğitim, ilk olarak, askerlik yükümlülüğünü yerine getiren Türk vatandaşlarına yöneliktir. Askerî eğitimin ikinci boyutu TSK'nın kendi aslî personelini yetiştirmeye yöneliktir. Türkiye'de askerî eğitim orta öğretime kadar inmiştir. TSK'nın askerî liseleri vardır. Bu uygulamanın dünya örnekleri ile kıyaslandığında son derece sıra dışı bir durum olduğu belirlenmiştir ${ }^{82}$. TSK'nın Askerî Liseleri 211 sayılı Kanun'un 113. ve 114. maddelerine dayanılarak çıkarılan Silâhlı Kuvvetler Askerî Liseler Yönetmeliğii ${ }^{83}$ ile kurulmuştur. Yönetmelik'in 10. maddesine göre öğretim ve eğitimin amac1 "Millî Ĕgitim Bakanlı̆̆ının öngördü̈̆̈̈ temel kültür, bilgi ve beceriyi vermek, ATATÜRK ilkeleri doğrultusunda Silâhlı Kuvvetlerin gerektirdiği temel askerî bilgi ve yetenekleri kazandırmaktır." Yönetmelik'in 11. ve 13. maddelerine göre askerî liselerin eğitim programı Millî Eğitim Bakanlığınca onaylanmakta ve Genelkurmay Başkanlığınca tescil edilmektedir.

TSK'nın orta öğretim sonrası askerî eğitim ve öğretimi, Anayasa'nın 132. maddesinde yükseköğretim olarak kabul edilmiştir. TSK yüksek öğretim kurumları Harp Okulları olarak adlandırılmaktadır. Harp okulları en

81 Erdoğan (2002), s. 242.

82 Janowitz, M.: The Military In The Political Development of New Nations, Chicago 1964, s. 62.

83 RG., 20.01.1976, S. 15474. 
son 11.05.2000 tarihli ve 4566 sayılı Harp Okulları Kanunu ile düzenlenmiştir. Yeni Kanun daha öncekinden farklı olarak tam bir üniversite teşkilât ve sistemini benimsemiștir. 4566 sayılı Kanun'a göre Harp Okulu "4.1.1961 tarihli ve 211 sayılı Türk Silâhlı Kuvvetleri İç Hizmet Kanununda belirtilen asker kişilerde bulunmasi gerekli niteliklere sahip..." (md. 4), "Atatürk ilkelerine bă̆lı ve askerî değerleri haiz muvazzaf subay yetiştiren; lisans ve lisans üstü düzeyde ĕgitim ve öğretim, bilimsel araştırma, yayın ve danışmanlık yapan, bilimsel özerkliğe sahip ${ }^{84}$ bir yüksek ögretim kurumudur." (md. 3/d).

Harp Okullarının bazı ana ilkeleri, "Öğrencilere Atatürk ilke ve inkllâpları doğrultusunda ve Atatürk milliyetçiliği, demokratik, laik ve sosyal hukuk devleti ilkelerine bağll hizmet bilincinin ve meslekî değerlerin kazandırllmast...", "Millî kültürümüz, örf ve âdetlerimize băglı şekil ve özellikleri ile evrensel değerler içinde korunarak, geliştiril(mesi) ve ögrencilere millî birlik ve beraberliği güçlendirici ruh ve irade gücü kazandirıl(mas1).."dır.

TSK'nın diğer bir yüksek öğretim kuruluşu Harp Akademileridir. Harp Akademileri 24.05.1989 tarihli ve 3563 sayılı Harp Akademileri Kanunu ile düzenlenmiştir. 3563 sayılı Kanun'un 2/a maddesine göre, Harp Akademileri "Genelkurmay Başkanlığı kuruluşunda, yüksek düzeyde akademik ĕgitim-ögretim yapan, Silâhl Kuvvetlere komutanlık ve karargâh subay niteliklerine sahip kurmay subay yetiştiren..., Silâhlı Kuvvetlerde, kamu yönetiminde ve gerektiğinde özel kesimde görevli üst düzey yöneticilerine millî güvenlik konularında bilgi ve yetenek kazandiran, özellikle stratejik konularda araştırma ve geliştirme yapan bilim ve ihtisas kuruluşudur."

Burada dikkati çeken en önemli konu, Harp Akademileri bünyesinde sivil ve memur kişilere de millî güvenlik konusunda eğitim verilmesidir. Bunun için 3563 say1lı Kanun'un 3/b maddesinde Harp Akademileri bünyesinde Millî Güvenlik Akademisi kurulmuştur. Kanun'un 12. maddesinde Millî Güvenlik Akademisi ve diğer akademilerde eğitim süresi 5 ay olarak belirlenmiştir. Öncelikle, yukarıda da belirttiğimiz gibi TSK'nın anayasal görevi doğrudan millî güvenliği değil, millî savunmayı sağlamaktır. Millî güvenliği sağlamak Bakanlar Kurulunun görevidir. Millî güvenliğin millî savunmaya ilişkin kısmı Bakanlar Kurulunun sorumluluğunda TSK tarafindan yürütülür. Dolayısıyla, millî güvenlik akademisinde, millî

84 Harp Okulları Kuvvet Komutanlıkları bünyesinde yer almaktadır (4566 sayılı Kanun md. 3/d). Bu nedenle Harp Okullarının bilimsel özerkliğe sahip yüksek öğretim kurumu olarak nitelendirilmesinin pek büyük bir anlamı yoktur. Bilimsel özerkliğin ön şartı idarî özerkliktir. Genelkurmay Başkanına kadar uzanan sert bir hiyerarşi içerisinde yer alan Harp Okullarının bilimsel özerkliğinden söz etmek güçtür. 
güvenlik konusunda sivil kişilere de eğitim verilmesi TSK'nın görevi olmasa gerekir. $\mathrm{Bu}$ tür bir hizmetin Başbakanlık ya da MGK bünyesinde yürütülmesi daha yerinde olurdu.

\section{TÜRK SILÂHLI KUVVETLERININ KOLLUK GÖREVI}

Savunma ve iç güvenlik işlevlerinin birbirinden ayrı tutulması, dolayısıyla da sivil iktidara bağlı askerî otoritenin sadece savunma ile ilgili olması, iç güvenlik sorumluluğunun yine sivil otorite ve ilgili bakanlıklarca üstlenilmesi demokratik bir sivil-asker ilişkisinin tesisi bakımından zorunludur $^{85}$. Diğer bir deyişle demokratik sistemlerde, her ikisinin sorumluluğu siyasal mercilerde bulunsa da, iç güvenlik ile dış güvenlik teşkilâtının ve işlevinin birbirinden ayrılması gerekir. Bu tür bir gereklilik bazı istisnaî durumlarda askerî gücün iç güvenlik alanında da kullanılmasına engel teşkil etmemelidir.

TSK'nın temelde dış güvenlik ya da millî savunma olarak tanımlanan görev alanı dışında, ihtiyaç duyulması halinde iç güvenlik alanında da görevlendirilmesi mümkündür. İç güvenlik örgütünün kamu düzeninin korunması konusunda yetersiz kaldığı istisnaî hallerde, TSK kamu düzenini korumak ve tesis etmek için kullanılabilir ${ }^{86}$. Burada esas olan sivil makamların belirleyici olmasıdır.

Daha önce de belirtildiği gibi, TSK'nın bir parçası olarak görülen Jandarma Genel Komutanlı̆̆g, polis örgütü bulunmayan yerlerde, sürekli olarak genel kolluk faaliyeti görmektedir. Ancak, Jandarma görev ve hizmet bakımından İçişleri Bakanlığına, askerî eğitim konusunda Genelkurmay Başkanlığına bağlıdır. Yine aynı şekilde Sahil Güvenlik Komutanlığı benzer bir statüde kolluk görevi görmektedir. Her iki silâhlı kuvvetler biriminin kolluk görevi istisnaî değil, süreklidir.

İç güvenlik ya da kamu düzeninin tesisi için askerî güçlerden yararlanılmasının esasları kanunla düzenlenmelidir. Nitekim, 04.06.1937 tarihli ve 3201 sayılı Emniyet Teşkilâtı Hakkında Kanun'un 1. maddesinin 2. fikrası, Bakanlar Kurulunun gereken durumlarda güvenlik ve asayişin sağlanması için silâhlı kuvvetlerden faydalanabileceğini düzenlemektedir. 10.6.1949 tarihli ve 5442 sayılı İl İdaresi Kanunu'nun 11/D maddesi, valinin kamu düzeninin sağlanamadığı olağanüstü durumlarda askerî birliklerden yardım isteyebileceğini düzenlemektedir. 5442 sayılı Kanun'un 32/E maddesi de, Kaymakamların ilçe düzeyinde askerî güçlerden yardım istemesini düzenlemektedir. 5442 sayıl1 Kanun'un 11/D maddesi acil durumlarda askerî güçlerden yardım istenmesini ayrıntılı bir biçimde

\footnotetext{
Tanör (1997), s. 75; Janowitz (1964), s. 38.

86 Güran, S.: “Genel Zabıta Faaliyetlerinde Askerî Kuvvetlere Başvurulması”, A.İ.D., C. 3, S. 1, 1970, s. 76; Erdoğan (2002), s. 238; Kıratlı (1973), s. 89.
} 
düzenlemiştir. Valinin olay özelinde askerî güçlerin yönetimi konusunda hiyerarşik amir konumunda olmadığını belirtmek gerekir. 5442 sayılı Kanun'un 11/D maddesine göre, “...Askerî kuvvetin müstakilen görevlendirilmesi durumunda; verilen görev askerî kuvvet tarafindan kendi komutanının sorumluluğu altında ve onun emir ve talimatlarına göre Türk Silâhlı Kuvvetleri İ̧ Hizmet Kanununda belirtilen yetkiler ile kolluk kuvvetlerinin genel güvenliği sağlamada sahip olduğu yetkiler kullanılarak yerine getirilir... askerî birliğin belirli görevleri jandarma ya da polis ile birlikte yapması halinde komuta, sevk ve idare askerî birliklerin en kıdemli komutan tarafindan üstlenilir."

TSK'nın kolluk yetkilerinden söz ederken sıkıyönetimin ayrı bir önemi vardır. Bilindiği gibi, sıkıyönetim olağan dışı bir yönetim biçimidir. Ülkede olağan dışı olaylarla, çözümü olağan yönetim biçimleriyle gerçekleştirilemeyecek sorunlarla karşılaşıldığında, temel hak ve özgürlüklerin daha katı bir biçimde sınırlanması, hatta askıya alınması gerektiği hallerde sıkıyönetim rejimi uygulanır ${ }^{87}$.

Sıkıyönetim, 1924 Anayasası'ndan beri Anayasalarımızda düzenlenmiştir. 1924 ve 1961 Anayasalarındaki düzenlemeler temelde aynıyd. Fakat, 1961 Anayasası'nda (md. 124), 1924 Anayasası'ndan farklı olarak sıkıyönetim halinde hangi özgürlüklerin sınırlanabileceği sayılmamıştı. Bu bakımdan 1924 Anayasası'nda düzenlenen sıkıyönetim rejimi, temel hak ve özgürlükler bakımından daha sağlam güvenceler öngörmekteydi.

12 Mart 1970 askerî müdahalesinin ardından gerçekleştirilen Anayasa değişikliklerinde sıkıyönetim rejimini düzenleyen 124. madde de ele alındı. Öncelikle, sıkıyönetim ilân edilebilecek hallere yenileri eklenerek sıkıyönetim ilân edilmesi kolaylaştırıldı. Ayrıca, Bakanlar Kurulunun sıkıyönetim uygulama süresi en fazla bir ay iken iki aya çıkarıldı.

1982 Anayasası sıkıyönetim uygulamasının katılaşma sürecinin son halkası oldu. Anayasa'nın 122. maddesinde düzenlenen sıkıyönetim rejimine yeni unsurlar eklendi. S1kıyönetimin Cumhurbaşkanı başkanlığında toplanacak Bakanlar Kurulunca ilân edilebileceği düzenlenerek sıkıönetim ilânı sürecine Cumhurbaşkanı da katıldı. Ayrıca Bakanlar Kurulunun sıkıyönetim ilân edebilmesi için MGK'dan görüş alınması zorunluluğu getirilerek TSK'nın sıkıyönetim ilânı sürecine doğrudan katılmasına olanak verildi. Bakanlar Kurulunun sıkıyönetim uygulama süresi altı aya çıkarıldı. Bakanlar Kuruluna farklı bir rejime tâbi Kanun Hükmünde Kararname çıkarma yetkisi verildi. Anayasa'nın 148/1. maddesi ile olağanüstü hal ve sıkıyönetim kanun hükmünde kararnamelerine karşı Anayasa Mahkemesinde

87 Üskül, Z.: Siyaset ve Asker, Ankara 1997, s. 27. 
dava açma olanağı kapatıldı. Sıkıyönetim komutanları Başbakana bağlı olmaktan çıkarılarak, siyasal iktidarın denetimi önlendi (Anayasa md. $122 / 6)^{88}$. S1k1yönetim komutanlarının 13.05.1971 tarihli ve 1402 sayılı Sıkıönetim Kanunu'nun 3. maddesinde sayılan yetkilerine bakıldığında, Genelkurmay Başkanına bağlanmasının ne kadar önemli bir hüküm olduğu anlaşılır. DURAN, TSK'nın özerk konumundan söz ederken "Sadece, 1982 Anayasası'nın sıkıyönetim komutanlarını, Başbakanlıktan ayırıp, Genelkurmay Başkanlığına bağlaması, kayda değer bir değişikliktir." demektedir ${ }^{89}$.

S1kıyönetim rejimine ilişkin düzenlemeler 12 Mart müdahalesinin ardından çıkarılan 1402 sayılı Kanun ile yapılmıştır. 1402 sayılı Kanun çeşitli tarihlerde yapılan pek çok değişiklikle neredeyse tamamen değişmiştir. En önemli değişiklikler, 12 Eylül askerî yönetimi tarafından 19.09.1980 tarih ve 2301 sayılı Kanun ile yapılmıştır. 1982 Anayasası'nın sıkıyönetime ilişkin hükümleri de ilginç bir yasama tekniğiyle 2301 sayılı Kanun ile yapılan değişikliklere uygun bir biçimde düzenlenmiştir ${ }^{90}$.

1402 sayılı Kanun'a göre sıkıyönetim ilân edilen bölgelerde bütün kolluk yetkileri sıkıönetim komutanına geçer ve kolluk teşkilâtı onun emrine girer (md. 2/1). S1kıyönetim komutanı sakıncalı gördüğg̈ kişileri sıkıyönetim bölgesinden çıkarabilir, sakıncalı gördüğü kamu görevlilerinin görevine son verebilir (md. 2/8). S1kıyönetim komutanı sıkıyönetim bölgesinde hemen hemen bütün temel hak ve özgürlüklere müdahale edebilir, onları sınırlandırabilir (md. 3). Sıkıönetim komutanının işlemlerine karşı iptal davası açılamaz, şahsî kusurları nedeniyle hukuksal sorumluluklarına gidilemez (Ek md. 3). Bu hüküm Anayasa'nın 125. maddesine aykırı olmakla birlikte, mevcut durumda sıkıyönetim ilan edilip uygulanıncaya kadar somut norm denetimini devreye sokmak mümkün değildir.

Gerek sıkıyönetim komutanının işlemlerine karşı dava açılamaması gerekse sıkıyönetim dönemlerinde çıkarılacak olan kanun hükmünde kararnamelere karşı Anayasa Mahkemesine başvuru olanağının tıkanması karşısında "...sıkıyönetim rejiminin bir 'hukuk rejimi' olduğunu söylemenin çok zor olduğu sonucu ortaya çıkıyor.""1

Görüldüğü gibi sıkıyönetimle ilgili mevcut düzenlemeler askerî gücün yayılması ve özerkleşmesi eğilimini pekiştirmiştir ${ }^{92}$.

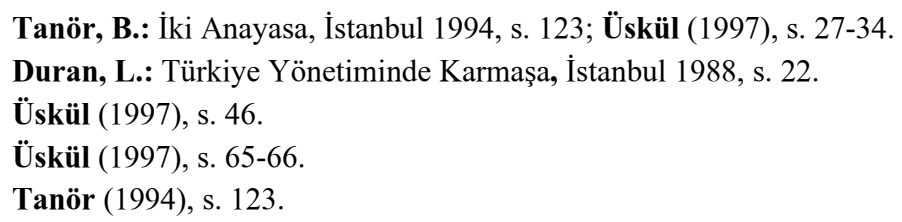


Türkiye'de sıkıyönetim uygulamalarının tarihine bakıldığında çok çarpıcı bir veriyle karşılaşılır. Cumhuriyetin ilanından 19.07.1997 tarihine kadar geçen 63 yıl 8 ay 20 günlük sürede, ülkenin çeşitli yerlerinde uygulanan sıkıyönetimin süresi 25 yıl 9 ay 18 gündür. Diğer bir deyişle, söz konusu dönemin \%40'inda ülkede sıkıyönetim, uygulanmıştır ${ }^{93}$. Tek başına bu veri bile TSK'nın ülkedeki etkinliğini ve ülke yönetiminde oynadığı rolün önemini tarihsel olarak ortaya koymaktadır.

\section{D) MÍLLî GÜVENLİK KAVRAMI VE MÍLLî GÜVENLİK KURULUNUN GÖREVLERİ}

Millî güvenlik kavramı tanımlanması gerçekten güç olan bir kavramdır ${ }^{94}$. Millî güvenlik kavramı, ilk etapta millî savunma ve askerî konuları çağrıştırsa da bundan çok daha geniş alanları kapsamaktadır. Çünkü millî güvenlik sadece dıştan gelebilecek saldırı ve tehlikelere karşı değil, aynı zamanda içte çıkabilecek yaygın çatışma ve şiddet olaylarına karşı korunmayı da içerir ${ }^{95}$.

Danıştay, 1970 yılında verdiği bir kararda, millî güvenlik kavramının bir tanımını yapma ve içeriğini belirleme çabası göstermiştir. Danıştay konuyu incelerken millî güvenlik kavramını şu şekilde tanımlamıştır: "Yurt ölçüsünde beliren iç ve diş tehlikelere karşı Devlet tüzel kişiliğinin savunma ve güvenlik altına alınması." 96

$\mathrm{Bu}$ tanımın tahlilinden "millî güvenlik", "millî savunma", ve "kamu düzeni" kavramları arasındaki farklar çıkarılabilir. Millî savunma, Devletin esas olarak dış tehlike ve tecavüzlere karşı korunması olduğu halde, millî güvenlik aynı zamanda bu nitelikteki yurt içi olayları da kapsamaktadır ${ }^{97}$. Kamu düzeni ve millî güvenlik kavramları arasındaki fark da millî güvenliğin, iç güvenliği ilgilendiren kısmı bakımından aranmalıdır ${ }^{98}$. Kamu düzeninde düzenin bozulması genellikle yerel ve geçici niteliktedir. Buna karş1lık millî güvenliğin tehlikeye düşmesi, toplumun ve ülkenin yerleşmiş düzeninin bozulması anlamında çok daha genel bir düzensizliğin ifadesidir. Millî güvenliği bozucu eylemler, Devletin varlığına veya olağan işleyişine

93 Üskül (1997), s. 71. Türkiye sıkıyönetim uygulamalarının ayrıntılı tarihi için aynı esere bak1labilir.

94 Aybay, R.: "Millî Güvenlik Kavramı ve Millı Güvenlik Kurulu”, A.Ü.S.B.F.D., C. XXXIII, S. 1-4, 1979, s. 60; Akgüner (1983), s. 64; Duran (1981), s. 129.

95 Özay (2004), s. 201; Duran (1981), s. 129.

96 D., 12. Daire, E. 1969/4097, K. 1970/426, K.T. 05.03.1970, D.K.D., S. 1, 1971, s. 379426.

97 Duran, L.: "Sosyal Hareketler ve Millî Güvenlik", İktisat ve Maliye, C. XVII, S. 4, 1970, s. 169.

98 Akgüner (1983), s. 69. 
yönelen geniş kapsamlı ve uzun süreli eylemler olabilir. Toplumun siyasî, sosyal ve ekonomik işleyişini yıkmayı, sarsmayı veya zedelemeyi amaç edinmeyen eylemler millî güvenlikle ilgili görülemezler ${ }^{99}$.

Bu çerçevede, MGK'nın görevlerinin hangi alanlara inhisar ettiğini tespit etmek millî güvenlik kavramının belirsizliği karşısında oldukça güçtür. $\mathrm{Bu}$ nedenle MGK'nın görev alanının yasal düzenleme ile somutlaştırılması önem taşır. Gerek Anayasa'da, gerekse kuruluş yasasında ifade edilen görevler MGK'nın görev alanının belirlenmesi konusunda netlik taşımamaktadır. Aslında, MGK yerine, yukarıda söz ettiğimiz Millî Savunma Yüksek Kurulu gibi bir kuruluşla karşı karşıya olsak, görev itibariyle sadece "millî savunma" gibi daha açık bir kavramı ele alacaktık.

Anayasa'nın 118/3. maddesinde MGK'nın "Devletin varlı̆̆ ve bağgımsizlı̆̆l, ülkenin bütünlüğü ve bölünmezliği, toplumun huzur ve güvenliğinin korunması hususunda alınması zorunlu gördüğ̈̈ tedbirlere ait kararlar"ın Bakanlar Kurulunca değerlendirileceği düzenlenmiştir. Burada sayılan belli nitelikteki kararlar için ayrıca özel bir kural konulduğuna göre, MGK burada sayılanlar dışındaki konularda da kararlar alabilecek demektir ve bunların sayılanlar gibi Bakanlar Kurulunca değerlendirmeye alınması gerekmez. Böylece, Anayasa MGK'ya devletin varlığı, bağımsızlığı, ülkenin bütünlüğü, toplumun huzur ve güvenliği dışındaki konuların ötesinde karar alabilme yetkisini dolaylı olarak vermiştir. Anayasa'nın 118. maddesinin 3. fikrasında sayılan konuların millî güvenlik kavramının içine girdiği kabul edilebilirse de, bunlar dışında akla gelebilecek muhtelif konuların millî güvenlik kavramıyla olan ilgisinin belirsizliği, MGK'nın görev alanının genişlemesine olanak verir niteliktedir.

Anayasa'da MGK'nın görevleriyle ilgili iki madde daha bulunmaktadır. Anayasa'nın 120. ve 122. maddelerine göre Bakanlar Kurulunun olağanüstü hal ve sıkıönetim ilan edebilmesi MGK'dan bu konuda görüş almasına bağlıdır.

Millî güvenlik kavramı ve MGK'nın görev konuları bakımından Anayasa'nın 118. maddesinin 3. fikrasının doğurduğu belirsizliğin 2945 sayılı ve Millî Güvenlik Kurulu ve Millî Güvenlik Kurulu Genel Sekreterliği Hakkında Kanun ile giderildiğini söylemek güçtür. Bununla birlikte, 2945 sayılı Kanun'da 30.07.2003 tarih ve 4963 sayılı Kanun ile yapılan değişiklerle MGK'nın görevi ile ilgili belirsizliklerin bir ölçüde giderildiği söylenebilir. 2945 sayılı Kanun değiştirilmeden önce, Kanun'un 4. maddesinde MGK'nın görevleri dokuz bent halinde, genel ifadelerle uzun uzun sayılmıştı. Burada sayılan görevler arasında özellikle "c" ve "e" bentleri MGK'nın görev alanını neredeyse sınırsız bir biçimde

99 Duran (1970), s. 170; Akgüner (1983), s. 70. 
genişletmekteydi. 2945 sayılı Kanun'un 4. maddesinin (c) bendinde, "(Millî Güvenlik Kurulu) Devletin millî güvenlik siyasetini etkileyecek millî güç unsurlarını ve ülkenin siyasî, sosyal, iktisadî, kültürel ve teknolojik durum ve gelişmelerini sürekli takip ederek değerlendirir..." düzenlemesi yer almaktaydı. Yine ayın maddenin "e" bendinde "(Millî Güvenlik Kurulu) Anayasal düzeni koruyucu, millî birlik ve bütünlüğü sağlayıcl, Türk Milletini Atatürkçü düşünce, Atatürk ilke ve inkllâplart doğrultusunda ve milli ülkü ve değerler etrafinda birleştirerek millî hedeflere yönlendirici gerekli tedbirleri belirler..." hükmü getirilmişti. Burada sayılan konular MGK'nın görev alanının artık millî güvenlikle sınırlı olmadığını göstermekteydi. Görev alanının bu kadar genişlemiş olmasının MGK'yı neredeyse ikinci bir hükûmet haline getirdiği; Kurulun, her ay yaptığı toplantılarda ülkenin güncel sorunlarına ilişkin hemen hemen her konuyu ele almasının bu kanaati güçlendirdiği ileri sürülmüştü ${ }^{100}$. Kanun'da sayılan görevlere bakıldığında, merkezdeki yardımcı kuruluşlar arasında sayılsa da, MGK'nın idare teşkilâtı içinde oldukça önemli bir konumu olduğu kendiliğinden ortaya çıkmaktayd $1^{101}$.

Neyse ki, 30.07.2003 tarih ve 4963 sayılı Kanun ile 2945 say1l Kanun'un 4. maddesi tamamen değiştirilmiş, MGK'nın görevi tavsiye ve görüş bildirme olarak tanımlanmış; söz konusu tavsiye ve görüşlerin konusu da 2945 say1lı Kanun'un 2. maddesine göndermede bulunularak tespit edilmiştir. 2945 sayılı Kanun'un "Tanımlar” başlığını taşıyan 2. maddesi "Millî Güvenlik" kavramını tanımlamaktadır. Bu tanıma göre, "Millî Güvenlik; Devletin anayasal düzeninin, millî varliğının, bütünlüğünün, milletler arası alanda siyasî, sosyal, kültürel ve ekonomik dahil bütün menfaatlerinin ve ahdî hukukunun her türlü dış ve iç tehditlere karşı korunması ve kollanmasını," ifade eder. MGK'nın görev alanının 2945 sayılı Kanun'un 2. maddesindeki millî güvenlik kavramıla sınırlandırılmaya çalışılması kavramın doğasından kaynaklanan belirsizlikleri gidermese de, 2945 sayılı Kanun'un 4. maddesinin getirdiği yeni düzenlemelerin geçmişteki düzenlemeye oranla olumlu yönlerinin bulunduğunu belirtmek gerekir.

MGK'nın görevlerinden biri de Millî İstihbarat Teşkilâtı Müsteşarının atanmas1 ile ilgilidir. 01.11.1983 tarihli ve 2937 sayıl Devlet İstihbarat Hizmetleri ve Millî İstihbarat Teşkilâtı Kanunu'nun 13. maddesine göre Başbakanın inhası ve Cumhurbaşkanının onayıyla atanacak olan Millî İstihbarat Teşkilâtı Müsteşarının atanmasından önce atama işleminin MGK'da görüşülmesi gerekir.

$100 \quad$ Erdoğan (2002), s. 256.

101 Yıldırım (1999), s. 90-91. 


\section{TÜRK SILÂHLI KUVVETLERINIIN DENETIMI}

\section{A) İDARÎ DENETIM}

TSK'nın her idarî kuruluş gibi kendi iç denetimini gerçekleştirdiğinden kuşku yoktur. Biz burada idare düzeni içindeki denetim kuruluşları bakımından TSK'nın dış denetimini inceleyeceğiz. Böylece TSK'nın sivil denetimini ele almış olacağız. Devlet Denetleme Kurulu, Başbakanlık Yüksek Denetleme Kurulu ve Sayıştayın denetim yetkileri bu açıdan ele alınabilir.

Devlet Denetleme Kurulu (DDK) Anayasa'nın 108. maddesinde düzenlenmiştir. DDK Cumhurbaşkanlığı teşkilâtı içerisinde idarenin hukuka uygunluğunun, düzenli ve verimli şekilde yürütülmesinin ve geliştirilmesinin sağlanması amacıyla Cumhurbaşkanına bağlı olarak kurulmuştur (md. 108/1). DDK bütün kamu kurum ve kuruluşlarında kamu kurumu niteliğindeki meslek kuruluşlarında, her düzeydeki işçi ve işveren meslek kuruluşlarında kamuya yararlı derneklerle vakıflarda, her türlü inceleme, araştırma ve denetlemeleri yapar. Ancak, silâhlı kuvvetler ve yargı organları, DDK'nın görev alanı dışındadır (md. 108/2). Yargı organlarının DDK'nın görev alanı dışında tutulması anlaşılır bir durumken, TSK'nın DDK'nın görev alanı dişında tutulmasını anlamak güçtür. Anayasa'nın 108/2. maddesinin gerekçesinde "Hizmetin taşıdığı özellikler dolayısıyla Türk Silâhlı Kuvvetleri ve yargı organları dışında kalan tüm kamu kurum ve kuruluşlarının ..."102 denilerek TSK'nın DDK denetiminin dışında bırakılması temellendirilmeye çalışılmıştır. Yürütülen her idarî faaliyet türünün kendine özgü gerekleri vardır. Ancak, TSK'nın DDK'nın yetki alanının dışında tutulmasına sebep gösterilebilecek bir hizmet özelliği ve gereği düşünmek son derece güçtür. Eğer bu gerekçe doğru ise, TSK'nın başkomutanlığının Cumhurbaşkanınca temsil olunacağını düzenleyen Anayasa'nın 117. maddesi karşısında gözden kaçmayacak ciddî bir çelişki vardir.

Bir diğer idarî denetim yeri Başbakanlık Teftiş Kuruludur. 10.10.1984 tarihli ve 3056 sayılı Başbakanlık Teşkilâtı Hakkındaki Kanun Hükmünde Kararnamenin Değiştirilerek Kabulü Hakkında Kanun'un 20. maddesine göre Başbakanlı Teftiş Kurulu bütün kamu kurum ve kuruluşlarını denetlemeye yetkilidir. TSK da bir bütün olarak kamu kuruluşu olduğuna göre Başbakanlık Teftiş Kurulunun TSK'yı denetleme yetkisinin bulunduğu açıktır. Esasen TSK'nın en üst düzey amiri olan Genelkurmay Başkanının Başbakana karşı sorumlu olduğu düşünüldüğünde böyle bir denetim aracının varlığı da gereklidir. Aksi halde söz konusu sorumluluğun işletilebilmesi olanağı büyük ölçüde kalkmış olacaktır.

102 Akad/Dinçkol (1998), s. 436. 
TSK, Sayıştay tarafindan da denetlenmektedir. Fakat bu denetleme özel usullerle yerine getirilir. Anayasa'nın Sayıştayı düzenleyen 160. maddesinin 4. fikrası "Silâhlı Kuvvetler elinde bulunan Devlet mallarının Türkiye Büyük Millet Meclisi adına denetlenmesi usulleri Millî Savunma hizmetlerinin gerektirdiği gizlilik esaslarına uygun olarak kanunla düzenlenir." hükmünü taşımaktayd ${ }^{103}$. Anayasa Mahkemesi 07.11.1985 tarih ve 3238 sayıl Kanun uyarınca yapılacak savunma sanayii harcamalarının Sayıştay denetimi dışında bırakılmasını Anayasa'nın 160. maddesinin 4. fikrasına istinaden Anayasa'ya aykırı bulmamıştı ${ }^{104}$.

Anayasa'nın 160. maddesinin 4. fikras1 07.05.2004 tarih ve 5170 sayılı Kanun'un 9. maddesi ile yürürlükten kaldırılmıştır. Ancak bu hüküm sadece Anayasa'dan kaldırılmıştır. Çünkü benzer bir hüküm 30.07.2003 tarih ve 4963 sayılı Kanun'un 7. maddesi ile 832 sayılı Sayıştay Kanunu'na eklenen Ek 12. madde ile düzenlenmiştir. 832 sayılı Kanun'un Ek 12. maddesinin 2. fikrasına göre, "Silâhlı Kuvvetlerin elinde bulunan Devlet mallarının denetlenmesi, millî savunma hizmetlerinin gerektirdiği gizlilik esaslarına uygun olarak yapılır. Bu denetimin yapılmasına ilişkin esas ve usuller, Genelkurmay Başkanlığının ve Sayıștayın görüşü alınmak suretiyle Millı̂ Savunma Bakanlığ tarafindan hazırlanarak Bakanlar Kurulunca kabul edilen "GIZLI' gizlilik dereceli bir yönetmelikle düzenlenir." Söz konusu yönetmelik gizli olduğu için Sayıştayın Silâhlı Kuvvetlerin elindeki Devlet mallarını denetlemesinin ayrıntıları üzerinde durmak mümkün değildir. Yine 832 sayılı Kanun'un 38. maddesinin son fikrasına göre, "Askerî kadrolarla askerî teçhizat, levazım, ayniyat, fabrika ve müesseseler, Sayıştay denetimine tâbidir. Ancak, bunların denetim usulleri, Saylştayın görüşü alındıktan sonra Millî Savunma ve Maliye Bakanlıklarınca yapılacak bir yönetmelikte belirtilir."

Sayıştayın TSK'yı denetimi hizmet gerekleri, gizlilik gibi sebeplerle ayrı bir yönteme tâbi tutulmuştur. " 'Gizlilik' konusunun askerî harcamalar üzerinde bir örtü şeklinde anlaşıldığı bu eğilim, bir yanda Anayasa'daki parlamento adına Sayıştaya malî denetim yetkisini veren düzenlemenin özüne aykırı olurken; öte yanda askerî harcamaların parlamento denetiminden kaçırılmasına yol aç(t)

\section{B) YARGISAL DENETIM}

Anayasa'nın 125/1. maddesine göre idarenin her türlü eylem ve işlemine karşı yarg1 yolu açıktır. Dolayısıyla TSK'nın eylem ve işlemlerinin

103 Anayasa'nın bu düzenlemesi 1961 Anayasası'nda da yer almaktaydı ve 1961 Anayasası'na 1971 değişiklikleriyle girmişti.

104 A.M., E. 1986/1, K. 1987/10, K.T. 05.05.1987, A.M.K.D., S. 23, s. 198.

105 Özdemir (1989), s. 230. 
de yargı denetimi altında olduğu şüphesizdir. Bu makalenin sonlarına doğru, TSK'nın yargısal denetiminin kendine özgü yönlerinin bulunduğunu söylemek artık şaşırtıcı olmaktan çıkmış olsa gerek.

Öncelikle, Anayasa'nın 125/2. maddesi YAŞ kararlarını yarg1 denetiminin dışına çıkarmıştır. Askerî Yüksek İdare Mahkemesi (AYİM), yerleşik kararlarında YAŞ kararlarına karşı açılan iptal ve tam yargı davalarını reddetmektedir ${ }^{106}$. YAŞ gibi bir kurulun varlığı millî savunma hizmetinin ve asker kişilerin statülerine ilişkin özelliklerin bir gereği olarak savunulabilir. Ancak yine askerî hizmetin kendine özgü gerekleri mülahazasıyla kurulan AYIMM varken YAŞ kararlarını yargı denetimi dışında bırakmanın mantıklı bir gerekçesini bulmak gerçekten zordur ${ }^{107}$.

Anayasa'nın 129/3. maddesi "Uyarma ve kinama cezalarlyla ilgili olanlar hariç, disiplin kararları yargı denetimi dışında bırakılamaz." hükmünü getirdikten sonra, 4. fikrada "Silâhlı Kuvvetler mensuplarl ile hâkimler ve savcllar hakkındaki hükümler saklıdır." kaydını getirmiştir. Demek ki, TSK mensupları hakkında verilen disiplin cezaları yargı denetiminin dışında bırakılabilir. Nitekim 1602 sayılı Askerî Yüksek İdare Mahkemesi Kanunu'nun 21. maddesinin son fikrasına göre, “...disiplin suç ve tecavüzlerinden ötürü disiplin amirlerince verilen cezalar yargı denetimi dışındadır."

106 AYiM, 1.D., E. 1995/1098, K. 1996/212, KT. 19.3.1996, AYIM Dergisi, S. 11, s. 991992; AYİM, 1.D., E. 1996/21, K. 1996/119, KT. 23.1.1996, AYİM Dergisi, S. 11, s. 988991; AYIM, 1.D., E. 1998/240, K. 1998/1028, KT. 8.12.1998, AYIM Dergisi, S. 13, s. 969-971; AYIMM, 1.D., E. 1997/1041, K. 1998/1059, KT. 15.12.1998, AYIMM Dergisi, S. 13, s. 957-966. Bununla birlikte, AYİM'in bu konuda iki ayrıksı kararı bulunmaktadır. Bunlardan biri, idarenin sakat bir işlemi nedeniyle bir albayın YAŞ kararı ile emekliye sevk edilmesine ilişkindir. Bu davada, davacı, hatalı işlem dolayısıyla emekliye sevk edildiği için tam yargı davası açmış ve AYİM YAŞ kararından önceki idarî işlemin sakatlığına binaen tazminata hükmetmiştir. AYİM, Daireler Kurulu, E. 1994/18, K. 1995/31, KT. 18.12.1995, AYIM Dergisi, S. 12, s. 1067-1072. AYIM bu kararını, bir başka kararda emsal olarak değerlendirirken zincir işlem kuramından yola çıkarak şu sonuca varmıştır: "...926 Sayll Kanunun 50'nci maddesinde öngörülen bekleme süresini doldurmadikları halde Kuvvet Komutanlıklarınca doldurmuş oldukları değerlendirildiğinden, Yüksek Askerî Şûra kararı kapsamında tutuldukları tespit edilerek talepleri üzerine tazminat istemeleri de kabul edilmiştir." "...tazminat istemleri kabul edilen iki albay ayrica kadrosuzluktan emekli edilmelerine ilişkin işlemi de dava etselerdi bu davaların kabulüne karar verilirdi. Zira, aksi halde tazminat istemlerinin de kabulüne olanak da kalmazdr." AYİM, 1.D., E. 1997/147, K. 1998/200, KT. 22.1.1998, AYİM Dergisi, S. 12, s. 1138, 1148. AYIMM diğer bir kararında, malulen emekliye sevk edilmek üzere olan TSK personelinin, YAŞ kararıyla disiplinsizlikten emekliye sevk edilme işleminin yokluğuna hükmetmiştir. AYİM, 1.D., E. 1997/147, K. 1998/200, KT. 22.1.1998, AYİM Dergisi, S. 12, s. 1151.

107 Erdoğan (2002), s. 262. 
TSK'nın yargısal denetiminin kendine özgü bir diğer boyutu, yargısal denetimin askerî bir yarg1 yeri tarafından gerçekleştiriliyor olmasıdır. TSK'nın idarî eylem ve işlemlerinin yargısal denetimini Askerî Yüksek İdare Mahkemesi (AYİM) yapmaktadır. AYİM yarg1 düzenine 1961 Anayasası'nda yapılan 1971 değişiklikleriyle girmişti (md. 140/son). AYİM'in yargı sistemine girmesiyle askerî hizmete ilişkin ve asker kişilerle ilgili idarî eylem ve işlemlerin yargı denetimi Danıştaydan alınmış ve İdarî Yargının birliği zedelenmiştir ${ }^{108}$.

1971 askerî darbesinin ardından gerçekleştirilen Anayasa değişiklikleriyle AYİM'in kurulması askerî alanın özerkleşmesinin ve askerî gücün sivil denetimden styrılma isteğinin verilerinden biri olarak kabul edilmektedir ${ }^{109}$.

1982 Anayasası'nda da yerini bulan AYİM, yüksek mahkemeler arasında sayılmıştır. AYİM askerî olmayan makamlarca tesis edilmiş olsa bile, asker kişileri ilgilendiren ve askerî hizmete ilişkin uyuşmazlıkları çözen ilk ve son derece mahkemesidir (Anayasa md. 157/1).

AYİM'in yargıç sınıfından olan üyeleri, mahkemenin bu sınıftan olan başkan ve üyelerinin tamsayısının salt çoğunluğuyla ve gizli oyla birinci sınıf yargıçlar arasından her boş yer için gösterilecek üç aday içinden, Cumhurbaşkanı tarafından seçilir. AYİM'in bir kısım üyeleri yargıç sınıfından değildir. Yargıç sınıfından olmayan üyeler, yasada gösterilen rütbe ve nitelikteki subaylardan her boş yer için Genelkurmay Başkanınca gösterilecek üç üye arasından Cumhurbaşkanınca atanır (Anayasa md. $157 / 2)$.

AYİM, 25.01.1981 tarihli ve 2568 say1lı Kanun ile büyük ölçüde değișikliğe uğramıș olan, 04.07.1972 tarih ve 1602 sayılı Askerî Yüksek İdare Mahkemesi Kanunu ile düzenlenmiştir. Bu Kanun'un gerekçesinde AYİM'in varlığını gerekli kılan sebepler ilginç bir biçimde açıklanmıştır:

"Danıştay'ın, askerin özlük işlerini sivil idareye paralel bir açıdan ele alması, silâhlı kuvvetlerin hizmet gereklerine ters düşmekte; çok defa iddia ve savunma icabı, askerlerin ve hatta yalnız belli askerî otoritelerin bilmesi gereken çok gizli askerî sırların açıklanması mecburiyetinde kalınmaktadır. Bu nedenle, Türk Silâhlı Kuvvetlerinin hizmetlerinden doğacak uyuşmazlık ve çekişmelerin en iyi şekilde ve yine askerler tarafından takdir edilip çözümlenebileceği ilkesi benimsenmiştir..." ${ }^{110}$

108 Duran (1988), s. 236-237; Tanör (1994), s. 54-55.

109 Tanör (1994), s. 54-55. "...12 Mart dönemi anayasa değişiklikleri parlamentonun özgür irade ve inisiyatifinin eseri değildir; TSK'nın 'mutlak isteği ve baskısı' sonucu gerçekleşmişlerdir." Tanör (1994), s. 53.

110 Gözübüyük, Ş./Tan, T.: İdare Hukuku (İdarî Yargılama Hukuku), C. II, Ankara 1999, s. 79-80. 
Burada yine, askerî alan için getirilen bütün ayrıksı düzenlemelerde ifade edilen askerî hizmetin gerekleri, gizlilik vs. gibi gerekçelerle karş1laşmaktayız. 1602 sayılı AYİM Kanunu, 1971 askerî müdahalesinin ardından ordunun doğrudan isteği ve etkisi altında çıkarılan bir kanundur. Dolayısıyla, yasanın gerekçesi ordunun gerekçesidir ve ordunun sivil yargıya olan güvensizliğini açıça ifade etmektedir. AYİM'in varlığı, TSK'nın özerkleşme eğiliminin doruk noktalarından biridir.

\section{SONUÇ}

TSK'nın idarenin bir unsuru olarak idarî teşkilât içindeki yeri en azından bir takım belirsizlikler nedeniyle kendine özgüdür. Söz konusu kendine özgülüğün ilk sebebi TSK'nın bir bakanlık bünyesinde örgütlenmemiş olmasıdır. İkinci olarak TSK'nın komutanı, diğer bir deyişle en yüksek hiyerarşik amiri olan Genelkurmay Başkanı Başbakana karşı sorumlu kılınmakla birlikte, söz konusu sorumluluğun mahiyetini ya da bunun ne anlama geldiğini ortaya koyacak herhangi bir yasal düzenleme mevcut değildir. Başbakan ile Genelkurmay Başkanı arasındaki ilişkinin ayrıntıları yasal düzenlemelerle belirlenmemiştir. Silâhlı kuvvetlerin sivil iktidarla olan ilişkisinin sivil iktidara tâbi olma gerekleri bakımından belirsizlikler taşıması kabul edilebilir bir durum değildir. Genelkurmay Başkanının Başbakana karşı sorumlu olduğunun belirtilmesi yeterli değildir. Bunun yanında, Genelkurmay Başkanlığının Başbakanlığa bağlı olduğunun da düzenlenmiş olması gereklidir. Genelkurmay Başkanlığının Başbakanlığa bağlı olduğunun yasayla düzenlenmesi Anayasa'ya aykırı düşmez. Bu tür bir düzenleme TSK'nın sivil iktidara bağlı olduğunu, en azından normatif olarak ortaya koyacaktır.

TSK'ya ilişkin mevzuatın izini sürdüğümüzde TSK'nın idare teşkilâtı içinde özerk bir konumu bulunduğu ortaya çıkmaktadır. TSK ve sivil iktidar arasındaki ilişkinin belirsizliği bu özerkliği besleyen önemli unsurlardan biridir.

TSK'nın aslî görevi millî savunma olmakla birlikte, özellikle 211 sayılı İç Hizmet Kanunu düzenlemelerinde yer alan Cumhuriyeti iç tehditlere karşı korumak görevi son derece ciddî belirsizliklere gebedir.

TSK'ya ilişkin hukuksal düzenlemeler özellikle yerindelikleri açısından eleştirilebilir. Başta Anayasa olmak üzere TSK'ya ilişkin düzenlemelerin en hassas olanları askerî darbelerin izlerini taşımaya devam etmektedir. Silâhlı kuvvetlerin siyasal tarihimizdeki rolü ile hukuksal düzenlemelerin oluşturduğu yapı arasında öylesine sıkı bir bağ vardır ki, sivil iradenin bu konudaki belirleyiciliği son derece tartışmalıdır. Ancak, özellikle MGK'ya yönelik son yasal değişiklikler bu durumun devam etmeyeceğinin ilk sinyallerini vermektedir. 


\section{KAYNAKÇA}

AHMAD, F., Demokrasi Sürecinde Türkiye, Çev: Fethi, A., İstanbul 1996.

AKAD, M.-DİNÇKOL, A., 1982 Anayasası, Madde Gerekçeleri ve Maddelerle İlgili Anayasa Mahkemesi Kararları, İstanbul 1998.

AKGÜNER, T., 1961 Anayasasına Göre Millî Güvenlik Kavramı ve Millî Güvenlik Kurulu, İstanbul 1983.

AYBAY, R., "Millî Güvenlik Kavramı ve Millî Güvenlik Kurulu”, A.Ü.S.B.F.D., C. XXXIII, S. 1-4, 1979, s. 59-82.

BALTA, T. B., İdare Hukukuna Giriş, Ankara 1968/1970.

DERBİL, S., İdare Hukuku, Ankara 1959.

DEMİRKOL, S./BEREKET, Z., İdarî Yargıda Dava Açma ve Davaların Takip Usulü, Ankara 1998.

DURAN, L., İdare Hukuku (Ders Notları), İstanbul 1981.

DURAN, L., Türkiye Yönetiminde Karmaşa, İstanbul 1988.

DURAN, L., "Sosyal Hareketler ve Millî Güvenlik", İktisat ve Maliye, C. XVII, S. 4, 1970, s. 165-172.

DOĞRUER, S., Askerler İçin Hukuk Rehberi, Kara Harp Okulu Komutanlığı yayını, Ankara 1998.

ERDOĞAN, M., Anayasa ve Özgürlük, Ankara 2002.

GÖZÜBÜYÜK, Ş./TAN,T., İdare Hukuku, C. I, 3. Baskı, Ankara 2004.

GÖZÜBÜYÜK, Ş./TAN, T., İdare Hukuku (İdarî Yargılama Hukuku), C. II, Ankara 1999.

GÜNDAY, M., İdare Hukuku, 8. Baskı, Ankara 2003.

GÜRAN, S., "Genel Zabıta Faaliyetlerinde Askerî Kuvvetlere Başvurulması”, A.İ.D., C. 3, S. 1, 1970, s. 76-104.

JANOWITZ, M., The Military In The Political Development of New Nations, Chicago 1964.

KIRATLI, M., Koruyucu İdarî Hizmetler, Ankara 1973.

ONAR, S. S., İdare Hukukunun Umumi Esasları, C. II, İstanbul 1966.

ÖZDEMİR, H., Rejim ve Asker, İstanbul 1989.

ÖZTÜRK, M., Ordu ve Politika, Ankara 1993.

ÖZAY, İ. H., Günışı̆̆ında Yönetim, İstanbul 2004.

SOYSAL, M., 100 Soruda Anayasanın Anlamı, 11. Baskı, İstanbul 1997.

SERİM, B., Anayasa ve Anayasa Mahkemesi Kararları Işı̆̆ında Özelleştirme, Ankara 1996. 
TANILLİ, S., Nasil Bir Demokrasi İstiyoruz?, İstanbul 1994.

TANÖR, B., İki Anayasa 1961-1982, İstanbul 1994.

TANÖR, B., Türkiye'de Demokratikleşme Perspektifleri, Tusiad Yayını, İstanbul 1997.

TURHAN, M., Hükümet Sistemleri ve 1982 Anayasası, Diyarbakır 1989.

ÜSKÜL, Z., Siyaset ve Asker, Ankara 1997.

YAYLA, Y., Anayasa Hukuku (Ders Notları), İstanbul 1986.

YILMAZ, E., "Ordu Yardımlaşma Kurumunun Hukuksal Niteliği", A.İ.D., C. 22, S. 1,1989 , s. 67-76.

YILDIRIM, T., Türkiye'nin İdarî Teşkilâtı, 2. Baskı, İstanbul 1999. 